\title{
Solvent-free synthesis of benzothiazole-based quaternary ammonium salts: precursors to ionic liquids
}

\author{
Sohail Nadeem, ${ }^{\text {a }}$ Munawar A. Munawar, ${ }^{* a}$ Saeed Ahmad, ${ }^{b}$ Marcin Smiglak, ${ }^{d}$ \\ David M. Drab, ${ }^{d}$ Khizar I. Malik, ${ }^{a}$ Rana Amjad, ${ }^{a}$ Chaudhry M. Ashraf, ${ }^{c}$ \\ and Robin D. Rogers*d \\ ${ }^{a}$ Institute of Chemistry, University of the Punjab, Lahore, Pakistan \\ ${ }^{b}$ Department of Chemistry University of Science and Technology Bannu, Pakistan \\ ${ }^{c}$ Forman Christian College a Chartered University, Lahore, Pakistan \\ ${ }^{d}$ Department of Chemistry and Center for Green Manufacturing, The University of Alabama, \\ Tuscaloosa, AL 35487, USA \\ E-mail: munawaralimunawar@yahoo.com, rdrogers@as.ua.edu
}

\begin{abstract}
This paper is dedicated to Professor Richard A. Bartsch on the occasion of his 70th birthday and retirement
\end{abstract}

DOI: http://dx.doi.org/10.3998/ark.5550190.0011.703

\begin{abstract}
A series of 13 benzothiazolium iodide salts have been prepared in solvent-free conditions by optimizing the reaction. An additional 26 benzothiazolium salts with bistrifluoromethanesulfonimide and trifluoromethylsulfonate were prepared via simple metathesis reactions from the iodide precursors. Out of a total of 39 prepared salts, 26 were identified as ionic liquids, with melting points as low as $42{ }^{\circ} \mathrm{C}$ observed for dodecylbenzothiazolium bistrifluoromethanesulfonimide. All prepared compounds have been characterized using FTIR, ${ }^{1} \mathrm{H},{ }^{13} \mathrm{C}$ NMR, and HRMS analyses. The thermal stabilities as well as melting points of these salts were also analyzed.
\end{abstract}

Keywords: Benzothiazolium iodides, ionic liquids, solvent free synthesis, quaternary ammonium salts

\section{Introduction}

It is now generally recognized that chemistry is one of the key sciences able to impact the environment in both a positive and negative fashion. As a result there is a growing awareness that the design of synthetic, or chemical processes, should follow the basic principles of green 
chemistry to reduce risks to humans and the environment. ${ }^{1,2}$ Among several aspects of green chemistry, the reduction/replacement of volatile organic solvents from the reaction medium is of utmost importance ${ }^{3}$ and one strategy that is now emerging is the use of low melting organic salts, called ionic liquids (ILs, currently defined as salts which melt below $100{ }^{\circ} \mathrm{C}$ ), as alternative solvents. ${ }^{4}$

Over the last two decades a lot has been learned about ILs, allowing a more balanced discussion about their possible 'greenness'. Many ILs have interesting properties that often can be tuned for particular applications just by simple variation of the constituent ions. In several cases ILs can have properties such as high thermal stability, low viscosity, high polarity, and low melting points that can be advantageous when considering ILs as volatile organic compounds replacement. In this light the growing interest in the use of ILs in organic synthesis as solvents, catalysts or reagents is expanding rapidly and this research field has been recently extensively reviewed by Martins et al., ${ }^{5}$ As these authors point out, since the initial reports of the use of ILs in organic synthesis, ILs are finding more and more applications in various organic reactions including homogenous and heterogeneous catalysis, transition-metal mediated catalysis, or even as solvents in bioorganic reactions. Nonetheless, it is equally clear that not all ILs have these properties and indeed some can be quite toxic or not suitable for particular processes. We have therefore been searching for new classes of compounds which might exhibit IL behavior in hopes of developing more benign solvents.

One class of potential cations of interest is based on benzothiazolium. Current literature reports of the use of this cation are limited, ${ }^{6-9}$ but it has been suggested that benzothiazolium salts posses catalytic activity ${ }^{10}$ in certain organic reactions ${ }^{11}$ such as benzoin condensations. ${ }^{12,13}$ Benzothiazoles have also found many applications in the field of dyes ${ }^{14}$ (e.g., direct yellow $7^{15}$ ) and in medicine where benzothiazolium salts play an important role in pharmaceuticals (e.g., Riluzole $^{16}$ is a benzothiazole-based drug that is used to treat amyotrophic lateral sclerosis).

Our objective for the work presented here, was to prepare a family of benzothiazolium-based salts utilizing solvent-free synthesis and at the same time expand the pool of available benzothiazolium salts by incorporation of different organic anions. In addition, from an IL point of view, the use benzothiazolium-based salts over the now commonly used imidazolium-based ILs, could offer cost savings (cheaper starting materials and facile syntheses) making them attractive to explore. ${ }^{17}$

Here we report the use of solvent-free methods for the quaternization of benzothiazole with a series of alkyl halides where no excess of reactant is being used while at the same time allowing for almost quantitative yield of the obtained products. Thirty nine $\mathrm{N}$-alkylated benzothiazolium salts were prepared with various alkyl chain lengths $\left(\mathrm{C}_{1}-\mathrm{C}_{12}\right)$ and paired with anions such as $\mathrm{I}^{-}$, $\left[\mathrm{Tf}_{2} \mathrm{~N}\right]^{-}$, and $\left[\mathrm{CF}_{3} \mathrm{SO}_{3}\right]^{-}$, out of which 26 were identified as ionic liquids, with melting points as low as $42{ }^{\circ} \mathrm{C}$ observed for dodecylbenzothiazolium bistrifluoromethanesulfonimide. The preparation, characterization, and analysis of these compounds are discussed below. 


\section{Results and Discussion}

\section{Synthesis of $\mathbf{N}$-alkyl benzothiazolium iodide salts}

A systematic strategy to prepare benzothiazolium chlorides, bromides, and iodides is limited by the reactivity of the alkyl halides used as alkylating agent which usually increases in the order $\mathrm{RCl}<\mathrm{RBr}<\mathrm{RI}$. We first attempted several $\mathrm{N}$-alkylation reactions of benzothiazole with alkyl chlorides in a pressure vial at temperatures of $50-180{ }^{\circ} \mathrm{C}$, but none of the $\mathrm{N}$ alkylbenzothiazolium chlorides attempted could be isolated in satisfactory yields. By contrast $\mathrm{N}$ alkylation of benzothiazole was successful using several different alkyl iodides under the optimized and relatively convenient conditions reported here. While we did not employ alkyl bromides in these reactions, we do believe based on our preliminary results that the use of alkyl iodides was dictated by their much higher reactivity than their bromide or chloride analogs.

Although many literature methods are available for the synthesis of $\mathrm{N}$-alkyl benzothiazolium iodides they require long reaction times, ${ }^{18,19}$ use of excess alkyl halide ${ }^{20}$ and the use of a solvent in order to obtain close to $100 \%$ yields. ${ }^{21}$ Our initial attempts to synthesize $N$-methylbenzothiazolium iodide using solvent-free conditions in the reaction of benzothiazole with iodomethane at different temperatures were successful, but the yield of the product was not comparable with the previously reported method. ${ }^{22}$ We then performed the reaction under ultrasonic irradiation at room temperature with equal mole ratios of reactants and without solvent resulting in $99.8 \%$ yield after $1 \mathrm{~h}$ (Table 1). Unfortunately, using these conditions with longer chain alkyl iodides gave unsatisfactory product yields (average c.a. 20\%). For these syntheses, conventional heating and stirring method was used and optimization of the reaction conditions led to good yields without use of solvents and with equal mole ratios of the reactants.

Thirteen $\mathrm{N}$-alkylbenzothiazolium iodide salts were obtained using temperatures from 30 to $200{ }^{\circ} \mathrm{C}$, depending on the alkyl halide chain length, for $2 \mathrm{~h}$ to $9 \mathrm{~h}$; (Scheme 1; Table 1). The reaction protocol was similar to that reported by Hor et al., ${ }^{22}$ for the solvent-free synthesis of five examples of $N$-alkylbenzothiazolium halides (including 2a, 3a, and 5a reported here), with the difference that the reaction times reported by Hor et al. were from overnight to $24 \mathrm{~h}$ with temperatures between room temperature and $80{ }^{\circ} \mathrm{C}$.

In general, the yields varied between 75 and $99 \%$. Each salt was analyzed by ${ }^{1} \mathrm{H}$ and ${ }^{13} \mathrm{C}$ NMR, FTIR, HRMS, and thermal analyses (DSC and TGA). Three of the iodide salts (12a, 13a, 14a) were successfully crystallized and single crystal $X$-ray diffraction analysis was carried out. 

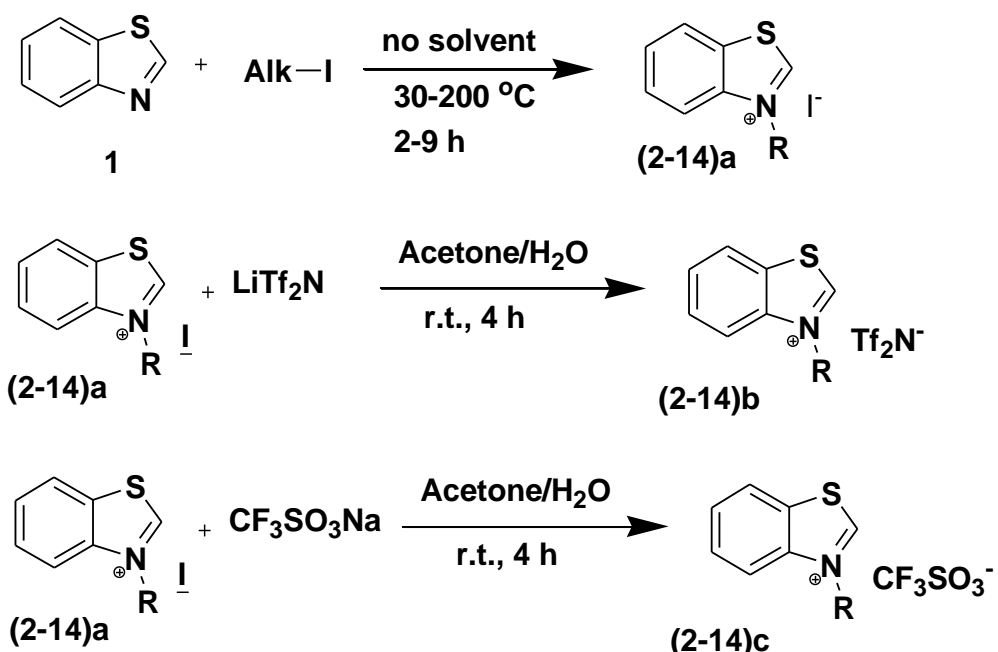

Scheme 1. Synthesis of $\mathrm{N}$-alkylbenzothiazolium iodide salts and further anion exchange reactions, where $\mathrm{R}=\mathrm{CH}_{3}(2) ; \mathrm{C}_{2} \mathrm{H}_{5}(3) ; \mathrm{C}_{3} \mathrm{H}_{7}$ (4); iso $\mathrm{C}_{3} \mathrm{H}_{7}(5) ; \mathrm{C}_{4} \mathrm{H}_{9}$ (6); $\mathrm{C}_{5} \mathrm{H}_{11}$ (7); $\mathrm{C}_{6} \mathrm{H}_{13}$ (8); $\mathrm{C}_{7} \mathrm{H}_{14}$ (9); $\mathrm{C}_{8} \mathrm{H}_{17}$ (10); $\mathrm{C}_{9} \mathrm{H}_{19}$ (11); $\mathrm{C}_{10} \mathrm{H}_{21}$ (12); $\mathrm{C}_{11} \mathrm{H}_{23}$ (13); $\mathrm{C}_{12} \mathrm{H}_{25}$ (14). (Syntheses of iodide salts 2a-9a, and 14a, and trifluoromethanesulfonate salts $\mathbf{2 c}$ and 9c have been previously reported, but the data available is limited to spectroscopic results without physical characterization. ${ }^{23-25}$

Table 1. Specific temperatures, reaction times, and yields for compounds (2-14)a (Scheme 1 top)

\begin{tabular}{ccccc}
\hline No. & R & $\begin{array}{c}\text { Yield } \\
\text { \% }\end{array}$ & $\begin{array}{c}\text { Temperature } \\
\mathbf{0} \text { C }\end{array}$ & $\begin{array}{c}\text { Time } \\
\mathbf{h}\end{array}$ \\
\hline $\mathbf{2 a}$ & $\mathrm{CH} 3$ & $82,99.8^{*}$ & $20-25$ & $\mathbf{9 . 0}$ \\
$\mathbf{3 a}$ & $\mathrm{C} 2 \mathrm{H} 5$ & 75 & $50-60$ & $\mathbf{4 . 0}$ \\
$\mathbf{4 a}$ & $\mathrm{C} 3 \mathrm{H} 7$ & 68 & $80-90$ & $\mathbf{6 . 0}$ \\
$\mathbf{5 a}$ & isoC3H7 & 62 & $70-80$ & $\mathbf{7 . 0}$ \\
$\mathbf{6 a}$ & $\mathrm{C} 4 \mathrm{H} 9$ & 80 & $110-120$ & $\mathbf{5 . 5}$ \\
$\mathbf{7 a}$ & $\mathrm{C} 5 \mathrm{H} 11$ & 79 & $125-135$ & $\mathbf{1 . 0}$ \\
$\mathbf{8 a}$ & $\mathrm{C} 6 \mathrm{H} 13$ & 77 & $160-170$ & $\mathbf{3 . 0}$ \\
$\mathbf{9 a}$ & $\mathrm{C} 7 \mathrm{H} 15$ & 75 & $180-190$ & $\mathbf{4 . 0}$ \\
$\mathbf{1 0 a}$ & $\mathrm{C} 8 \mathrm{H} 17$ & 80 & $210-220$ & $\mathbf{4 . 0}$ \\
$\mathbf{1 1 a}$ & $\mathrm{C} 9 \mathrm{H} 19$ & 73 & $150-160$ & $\mathbf{2 . 0}$ \\
$\mathbf{1 2 a}$ & $\mathrm{C} 10 \mathrm{H} 21$ & 70 & $110-120$ & $\mathbf{4 . 5}$ \\
$\mathbf{1 3 a}$ & $\mathrm{C} 11 \mathrm{H} 23$ & 75 & $95-105$ & $\mathbf{3 . 0}$ \\
$\mathbf{1 4 a}$ & $\mathrm{C} 12 \mathrm{H} 25$ & 72 & $140-150$ & $\mathbf{5 . 0}$ \\
\hline
\end{tabular}

*Reaction performed under ultrasonic irradiation at room temperature with equal mole ratios of reactants for $5 \mathrm{~h}$. 
Single crystals of 12a, 13a, and $\mathbf{1 4 a}$ could be isolated by slow evaporation from ethyl acetate and were characterized by single crystal X-ray diffraction. The crystal structures of all three compounds are quite similar and virtually isostructural. Each crystallizes in the triclinic space group P-1 with modest differences in the cell parameters. There is evidence of $+/$ - gauche disorder in the terminal $-\mathrm{CH}_{2} \mathrm{CH}_{3}$ group in each alkyl chain (Figure 1). This disorder could not be resolved for 13a, the $\mathrm{C} 11$ derivative, although the ellipsoids shapes for these carbon atoms suggest it is present. For the $\mathrm{C} 10$ (12a) and C12 (14a) derivatives, the disorder could be resolved and was modeled with 60/40\% occupancy for the two distinct orientations for 12a and 75/25\% occupancy for the disorder in $\mathbf{1 4 a}$.
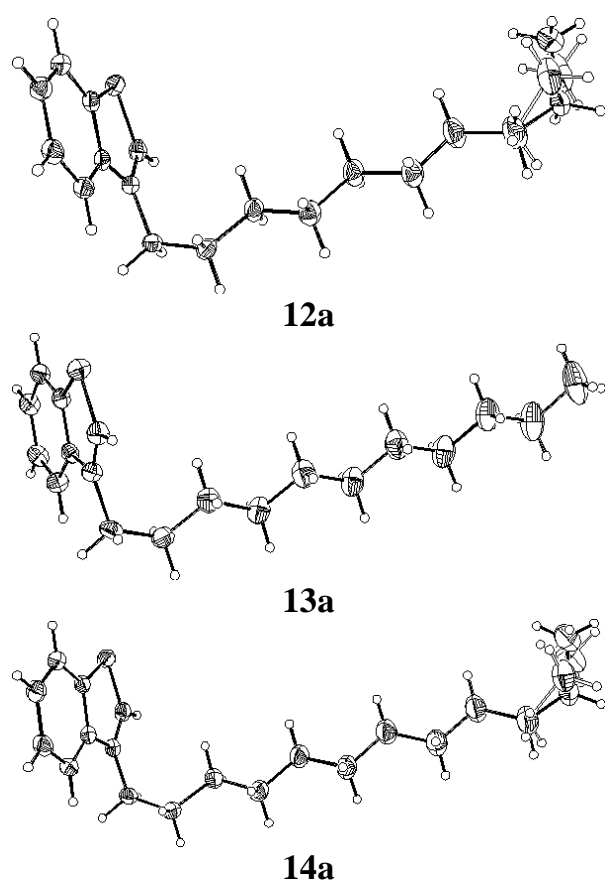

Figure 1. Plots with thermal ellipsoids (50\% probability) shown for crystal structures of 12a (top), 13a (middle) and 14a (bottom).

The ions pack in a bilayer-type structure with the alkyl chains interdigitated and the cation head groups and iodide ions forming a polar region. This type of packing has been observed previously in long alkyl chain imidazolium ionic liquids, ${ }^{26}$ as well as other similar molecules with polar head groups and long non-polar alkyl chains. ${ }^{27}$ There is no pi-stacking between cationic head groups. 


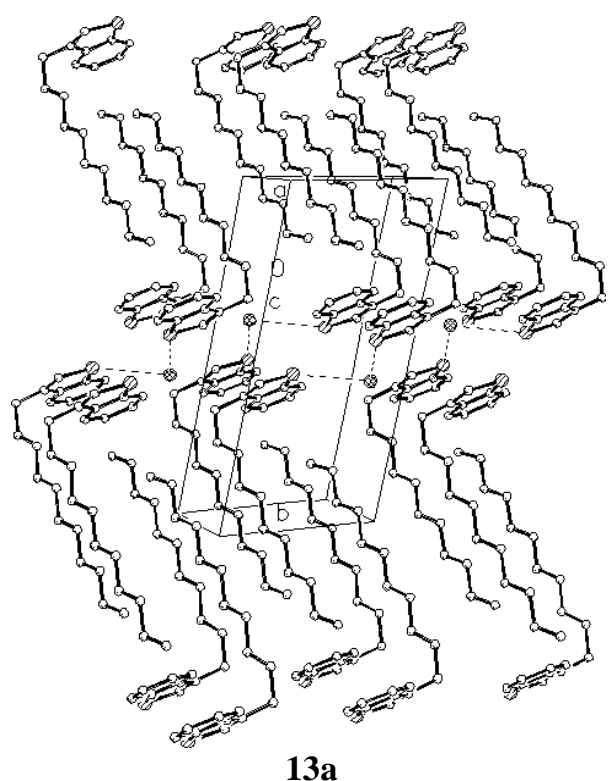

Figure 2. A packing diagram for 13a, where I $\bullet$ S contacts are shown (dashed lines). Hydrogen atoms have been omitted for clarity.

The iodide environments are characterized by short contacts to four cation head groups via

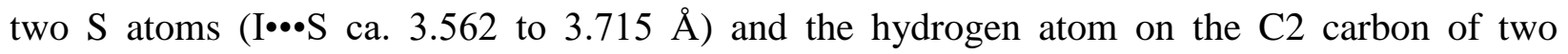

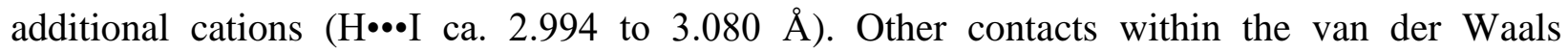
separation include hydrogen atoms of the alkyl chain, particularly the alpha carbon (C9) and terminal methyl carbon.

\section{Synthesis of $N$-alkyl benzothiazolium [NTf $]^{-}$(b) and [ $\left.\mathrm{CF}_{3} \mathrm{SO}_{3}\right]^{-}$(c) salts}

After successful preparation and purification of the iodide salts, solvent (acetone) assisted ion exchange metathesis reactions ${ }^{28-30}$ were carried out to prepare the $\left[\mathrm{NTf}_{2}\right]^{-}$and $\left[\mathrm{CF}_{3} \mathrm{SO}_{3}\right]^{-}$ derivatives resulting in preparation of 26 compounds out of which 24 are reported here for the first time. Literature reports vary from using absolutely anhydrous conditions ${ }^{31}$ to reactions in water ${ }^{32}$ for anion exchange reactions between $\mathrm{I}^{-}$and $\left[\mathrm{NTf}_{2}\right]^{-}$or $\left[\mathrm{CF}_{3} \mathrm{SO}_{3}\right]^{-}$anions. Here, for $1 \mathrm{~g}$ of iodide salt, $10 \mathrm{~mL}$ of acetone and a molar equivalent of the anion salt (i.e., $\mathrm{Li}\left[\mathrm{NTf}_{2}\right]$ or $\mathrm{Na}\left[\mathrm{CF}_{3} \mathrm{SO}_{3}\right]$ ) was added followed by stirring at room temperature for $4 \mathrm{~h}$. Purification and isolation of the new salts was performed by drying and further extraction of products with anhydrous ethyl acetate (absolute ethanol where necessary). Successful metathesis was checked by silver nitrate halide test. The anion exchange reactions gave yields above $80 \%$ and all of the obtained salts were analyzed by ${ }^{1} \mathrm{H}$ and ${ }^{13} \mathrm{C}$ NMR, FTIR, MS, DSC, and TGA. 


\section{Spectroscopic analyses}

All 39 reported benzothiazolium salts $(\mathbf{2 - 1 4}(\mathbf{a}-\mathbf{c}))$ were analyzed using FTIR, NMR, and HRMS in order to confirm their purity and structure. The FTIR spectroscopic data (presented in the experimental section) are in agreement with the few examples of previously reported $\mathrm{N}$ alkylbenzothiazolium iodides. ${ }^{33}$ The most intense and characteristic bands in FTIR spectra of the benzothiazolium core appear around $3000 \mathrm{~cm}^{-1}$ (C-H from Ar-H stretch), 2852-2924 cm-1 (C-H from $\mathrm{CH}_{2}$ stretch), 1635-1578 $(\mathrm{C}=\mathrm{C}), 1509-1524 \mathrm{~cm}^{-1}(\mathrm{C}=\mathrm{N}), 1428-1467 \mathrm{~cm}^{-1} \mathrm{CH}_{3}$ asymmetric deformation and $\mathrm{CH}_{2}$ deformation) and $757-781 \mathrm{~cm}^{-1}$ (skeletal "out of plane" vibration). It was observed that the intensity of the aliphatic $\mathrm{C}-\mathrm{H}$ absorption bands increased with the length of the $\mathrm{N}$-alkyl chain and appeared in the $2826-2994 \mathrm{~cm}^{-1}$ region.

The mass spectra were recorded in $\mathrm{CH}_{3} \mathrm{OH}$ solutions using a high resolution AutoSpect-Ultima NT Mass Spectrometer. It is obvious from the spectra that the molecular ion peaks are present corresponding to the cation structure of all the quaternary ammonium salts. The results are included in the experimental section.

\section{Thermal analyses (TGA, DSC)}

The thermal stabilities of the obtained salts were assessed using thermogravimetric analysis (TGA). In general all analyzed compounds exhibited onset decomposition temperatures ( $\mathrm{T}_{5 \% \mathrm{dec}}$ ) above $140{ }^{\circ} \mathrm{C}$. The thermal stabilities varied slightly with changes in the length of the alkyl chain, but greater variation was noted when changing the anion with the $\left[\mathrm{NTf}_{2}\right]^{-}$salts being the most stable. ${ }^{34}$ All of the $\left[\mathrm{NTf}_{2}\right]^{-}$salts decompose at temperatures above $240{ }^{\circ} \mathrm{C}$, with the maximum thermal stability of $\mathrm{T}_{5} \% \mathrm{dec}=326^{\circ} \mathrm{C}$ observed for $\mathbf{2 b}\left(\mathrm{R}=\mathrm{CH}_{3}\right)$. 
Table 2. Melting points and thermal stabilities ${ }^{\S}$

\begin{tabular}{|c|c|c|c|c|c|c|}
\hline \multirow{2}{*}{ Cation } & \multicolumn{2}{|c|}{$\begin{array}{l}\mathrm{I}^{-} \\
\text {(a) }\end{array}$} & \multicolumn{2}{|c|}{$\begin{array}{c}{\left[\mathrm{NTf}_{2}\right]^{-}} \\
\text {(b) }\end{array}$} & \multicolumn{2}{|c|}{$\begin{array}{c}{\left[\mathrm{CF}_{3} \mathrm{SO}_{3}\right]^{-}} \\
(\mathrm{c})\end{array}$} \\
\hline & $\begin{array}{l}\mathrm{mp} \\
\left({ }^{\circ} \mathrm{C}\right)\end{array}$ & $\begin{array}{c}\mathrm{T}_{5 \% \operatorname{dec}}\left(\mathrm{T}_{\mathrm{dec}}\right) \\
\left({ }^{\circ} \mathrm{C}\right)\end{array}$ & $\begin{array}{l}\mathrm{mp} \\
\left({ }^{\circ} \mathrm{C}\right)\end{array}$ & $\begin{array}{c}\mathrm{T}_{5 \% \operatorname{dec}}\left(\mathrm{T}_{\mathrm{dec}}\right) \\
\left({ }^{\circ} \mathrm{C}\right)\end{array}$ & $\begin{array}{l}\mathrm{mp} \\
\left({ }^{\circ} \mathrm{C}\right)\end{array}$ & $\begin{array}{c}\mathrm{T}_{5 \% \operatorname{dec}}\left(\mathrm{T}_{\mathrm{dec}}\right) \\
\left({ }^{\circ} \mathrm{C}\right)\end{array}$ \\
\hline 2 & $\begin{array}{l}221-222^{c} \\
(\text { lit } 216)^{23}\end{array}$ & $194(214)$ & 79.0 & $326(366)$ & $191-192^{c}$ & $145(184)$ \\
\hline 3 & $\begin{array}{l}136-137^{c} \\
(\text { lit } 140)^{23}\end{array}$ & $177(205)$ & $66.2^{\mathrm{a}}$ & $312(342)$ & $126.5^{\mathrm{a}, \mathrm{b}}$ & $162(202)$ \\
\hline 4 & $\begin{array}{c}158-159^{c} \\
(\text { lit } 158)^{23}\end{array}$ & $179(205)$ & $69.3^{\mathrm{a}}$ & $314(341)$ & $124.1^{\mathrm{a}}$ & $172(195)$ \\
\hline 5 & $\begin{array}{c}131.1^{\mathrm{a}, \mathrm{b}} \\
(\text { lit 131 })^{23}\end{array}$ & $181(205)$ & 88.3 & $244(274)$ & $118.3^{\mathrm{a}, \mathrm{b}}$ & $178(200)$ \\
\hline 6 & $\begin{array}{c}116.3 \\
(\text { lit } 114)^{23}\end{array}$ & $175(201)$ & 60.6 & 309 (339) & $106.1^{\mathrm{a}}$ & 170 (196) \\
\hline 7 & $\begin{array}{c}117.8^{a} \\
(\text { lit 119) }\end{array}$ & 172 (199) & $49.3^{\mathrm{a}}$ & $306(338)$ & $80.5^{a, b}$ & 165 (192) \\
\hline 8 & 126.7 & 173 (199) & $48.9^{\mathrm{a}}$ & $280(326)$ & $74.0^{\mathrm{a}, \mathrm{b}}$ & 163 (189) \\
\hline 9 & $65.1^{\mathrm{a}, \mathrm{b}}$ & 164 (193) & $39.6^{\mathrm{a}}$ & 303 (327) & $58.9^{\mathrm{a}, \mathrm{b}}$ & 167 (190) \\
\hline 10 & $74.5^{\mathrm{a}, \mathrm{b}}$ & $166(188)$ & $46.9^{a}$ & $302(327)$ & $70.2^{\mathrm{a}, \mathrm{b}}$ & $160(188)$ \\
\hline 11 & 82.1 $1^{\mathrm{a}, \mathrm{b}}$ & $162(186)$ & $46.3^{a}$ & $295(326)$ & $64.4^{\mathrm{a}, \mathrm{b}}$ & $161(188)$ \\
\hline 12 & $82.4^{\mathrm{a}, \mathrm{b}}$ & $171(194)$ & $49.5^{\mathrm{a}}$ & 304 (334) & $83.1^{\mathrm{a}, \mathrm{b}}$ & $164(187)$ \\
\hline 13 & $80.4^{a, b}$ & $161(188)$ & $44.2^{\mathrm{a}}$ & $300(359)$ & $75.3^{\mathrm{a}, \mathrm{b}}$ & $163(188)$ \\
\hline 14 & $90.5^{\mathrm{a}, \mathrm{b}}$ & $162(187)$ & $49.9^{a}$ & $299(326)$ & $80.2^{a, b}$ & $164(186)$ \\
\hline
\end{tabular}

[§] Melting (mp) or glass transition $\left(\mathrm{T}_{\mathrm{g}}\right)$ points $\left({ }^{\circ} \mathrm{C}\right)$ were measured from the transition onset temperature and determined by DSC from the second heating cycle at $10{ }^{\circ} \mathrm{C} \mathrm{min}{ }^{-1}$, after initially melting and then cooling samples to $-100{ }^{\circ} \mathrm{C}$. Decomposition temperatures shown were determined by TGA, heating at $10{ }^{\circ} \mathrm{C} \mathrm{min}-1$ under dried air atmosphere and are reported as (i) onset to $5 \mathrm{wt} \%$ mass loss $\left(\mathrm{T}_{5 \% \mathrm{dec}}\right.$ ) and (ii) onset to total mass loss ( $\left.\mathrm{T}_{\mathrm{dec}}\right)$ (in parentheses). Salts meeting the definition of ionic liquids $\left(\mathrm{mp}<100{ }^{\circ} \mathrm{C}\right)$ are in bold; [a] Sample exhibits additional glass transition temperatures $\left({ }^{\circ} \mathrm{C}\right)$ of supercooled liquids (i) with consecutive crystallization and melting on heating; $\mathbf{3 b},-42.7 ; \mathbf{4 b},-48.1 ; \mathbf{4} \mathbf{c},-17.3 ; \mathbf{5 c},-5.2 ; \mathbf{6 c},-4.4 ; \mathbf{7 a}, 2.3 ; \mathbf{7 b},-51.2 ; \mathbf{8 b},-47.6$; $\mathbf{9 b},-42.8 ; \mathbf{1 0 b},-43.5 ; \mathbf{1 1 b},-49.1 ; \mathbf{1 2 b},-58.2 ; \mathbf{1 3 b},-45.2 ; \mathbf{1 4 b},-48.1 ;\left({ }^{\circ} \mathrm{C}\right)$; (ii) with no crystallization and melting under experimental conditions: 3c, $-5.2 ; \mathbf{5 a}, 2.4 ; 7 \mathbf{c},-3.2 ; 8 \mathbf{c},-6.5 ; \mathbf{9 a}$, $-5.6 ; 9 \mathbf{c},-10.1 ; 10 a,-2.3 ; 10 c,-7.2 ; 11 a, 5.5 ; 11 c,-9.1 ; 12 a,-5.6 ; 12 c,-11.2 ; 13 a,-5.8 ; 13 c,-$ $11.1 ; \mathbf{1 4 a},-6.0 ; \mathbf{1 4 c},-10.3\left({ }^{\circ} \mathrm{C}\right)$; [b] Irreversible transition, from first heating; [c] melting point measured visually due to close proximity to the decomposition temperature and possibility of contamination of the DSC cell. 
The decomposition temperatures of the $\mathrm{I}^{-}$salts varied between $161{ }^{\circ} \mathrm{C}(\mathbf{1 3 a})$ and $194{ }^{\circ} \mathrm{C}(\mathbf{2 a})$, and for the $\left[\mathrm{CF}_{3} \mathrm{SO}_{3}\right]^{-}$salts between $145{ }^{\circ} \mathrm{C}(\mathbf{2 c})$ and $178{ }^{\circ} \mathrm{C}(\mathbf{5 c})$. Interestingly, the thermal stabilities of the $\mathrm{N}$-iso-propylbenzothiazolium $\mathrm{I}^{-}$and $\left[\mathrm{CF}_{3} \mathrm{SO}_{3}\right]^{-}$salts $(\mathbf{5 a}$ and $\mathbf{5 c})$ were found to be the among the highest of their respective homologs $\left(181{ }^{\circ} \mathrm{C}\right.$ and $178{ }^{\circ} \mathrm{C}$, respectively), but in the case of the $\left[\mathrm{NTf}_{2}\right]^{-}$salts, $\mathbf{5} \mathbf{b}$ had the lowest thermal stability $\left(244{ }^{\circ} \mathrm{C}\right)$.

Melting points were obtained using differential scanning calorimetry (DSC). All melting points were collected twice on different samples. Some of the crystalline salts exhibited a sharp melting transition on heating, and a crystallization event on cooling, however, the majority of the salts exhibited supercooled behavior, not allowing any direct observation of a crystallization event on cooling from the melt. For many of these samples, the melting transitions were poorly defined in the DSC, commonly having a characteristic broad transition with a strong "leading edge". (Such behavior has been previously observed for other examples of IL-forming salts. ${ }^{35}$ ) A few of the samples exhibited even more interesting behavior giving irreversible thermal transitions observable only during the first DSC heating cycle. The melting points and glass transitions for 2-14(a-c) are shown in (Table 2).

Among all analyzed salts, those of the $\left[\mathrm{NTf}_{2}\right]^{-}$anion exhibited the lowest melting points as it is often observed for salts with this anion. ${ }^{36}$ In this series of compounds, the melting points of the $\left[\mathrm{NTf}_{2}\right]^{-}$salts meet the definition of ILs (melting points less than $100{ }^{\circ} \mathrm{C}$ ) with melting points between $39.6{ }^{\circ} \mathrm{C}(\mathbf{9 b})$ and $83.3{ }^{\circ} \mathrm{C}(\mathbf{5 b})$. The melting points of the remaining salts ranged from $65.1{ }^{\circ} \mathrm{C}(\mathbf{9 a})$ to $221{ }^{\circ} \mathrm{C}(\mathbf{2 a})$ for $\mathrm{I}^{-}$based salts, and from $58.9^{\circ} \mathrm{C}$ (9c) to $191.0{ }^{\circ} \mathrm{C}$ (2c) for $\left[\mathrm{CF}_{3} \mathrm{SO}_{3}\right]^{-}$salts. In general across all the salts, the melting points decreased as the alkyl chain length increased, reaching a minimum melting point for all three families of salts with an alkyl chain length of 7 carbon atoms: $65.1{ }^{\circ} \mathrm{C}$ for $9 \mathbf{a}, 39.6{ }^{\circ} \mathrm{C}$ for $9 \mathbf{b}$, and $58.9{ }^{\circ} \mathrm{C}$ for $9 \mathbf{c}$. At $\mathrm{C} 8$ and above, the melting points increased. Six of the $\mathrm{I}^{-}$salts $(\mathbf{9 - 1 4 a})$, all of the $\left[\mathrm{NTf}_{2}\right]^{-}$salts $(\mathbf{2 - 1 4 b})$, and 8 of the $\left[\mathrm{CF}_{3} \mathrm{SO}_{3}\right]^{-}$salts $(\mathbf{7 - 1 4 c})$ had melting points below $100{ }^{\circ} \mathrm{C}$.

\section{Conclusions}

Thirteen $\mathrm{N}$-alkylated benzothiazolium iodides salts were prepared (4 compounds, 10a, 11a, 12a, and 13a, for the first time) using various alkyl iodides and solvent free conditions. Optimization of each reaction, primarily the reaction temperature, afforded good yields of these salts comparable or better to those previously reported. ${ }^{24,25,37}$ The yields were found to increase with increasing chain length of the alkylating agent. The iodide salts $\mathbf{2 - 1 4 a}$ were further used in ion exchange reactions to prepare the related $\left[\mathrm{NTf}_{2}\right]^{-}(\mathbf{2 - 1 4 b})$ and $\left[\mathrm{CF}_{3} \mathrm{SO}_{3}\right]^{-}(\mathbf{2 - 1 4 c})$ salts with almost quantitative yields. All prepared compounds were analyzed using spectroscopic and thermal techniques in order to evaluate their composition and thermophysical properties such as melting point and decomposition temperature. Among all of the 39 analyzed compounds, 26 can be classified as ionic liquids with melting points below $100{ }^{\circ} \mathrm{C}$. The lowest melting point was recorded for dodecylbenzothiazolium bistrifluoromethanesulfonimide $\left(\mathbf{1 4 b} ; 42{ }^{\circ} \mathrm{C}\right)$. 
Three crystal structures of long chain alkylbenzothiazolium iodides were analyzed (12-14a). All three are virtually isostructural and pack in a bilayer-type arrangement with the alkyl chains interdigitated and the cation head groups and iodide ions forming a polar region. Such packing characteristics have been observed previously in long alkyl chain imidazolium ILs, as well as other similar molecules with polar head groups and long non-polar alkyl chains.

\section{Experimental Section}

General. All reagents and chemicals were obtained from Sigma-Aldrich (St. Louis, MO). Solvents were of analytical grade. Reactions were monitored by thin layer chromatography using $0.20 \mathrm{~mm}$ aluminum-backed Silica Gel plates $\left(\right.$ Merck $\left.\mathrm{GF}_{254}\right)$. The plates were eluted with ethyl acetate/n-hexane in 1:2 ratio and the spots examined under UV light (254-365 nm). FTIR spectra were recorded on a Perkin Elmer FTIR Spectrum RX I. Characteristic absorptions are given in $\mathrm{cm}^{-1} .{ }^{1} \mathrm{H}$ NMR and ${ }^{13} \mathrm{C}$ NMR spectra were recorded in $\mathrm{CD}_{3} \mathrm{OD}$ on Bruker instruments of 500 $\mathrm{MHz}$ and $125 \mathrm{MHz}$, respectively. Chemical shifts are reported as $\delta$ values in ppm using TMS as the internal standard. Coupling constants $(\mathrm{J})$ are given in $\mathrm{Hz}$. High resolution mass spectra (HRMS) were recorded on Autospec-Ultima NT.

\section{Synthesis of quaternary ammonium salts}

The general method used for the synthesis of quaternary ammonium salts of benzothiazole was as follows: a solution of benzothiazole and the corresponding alkyl iodide, in equimolar quantities, was stirred and heated in a dry $10 \mathrm{~mL}$ round bottom flask fitted with a reflux condenser carrying a $\mathrm{CaCl}_{2}$ drying tube at the other opening end. The heating temperature range and the time required for each salt is mentioned in Table 1. After the desired time, the reaction mixture was slowly cooled which in most cases solidified or became a thick semi-solid mass. The crude products were triturated with ethyl acetate and filtered. The starting materials were freely soluble in ethyl acetate in contrast to the products which were sparingly soluble in this solvent, allowing for efficient purification. In most of the cases, a precipitate of the product was readily obtained just after the dissolution, while in a few cases the mixture was put in a freezer for precipitation. The filtered crude products were washed with ethyl acetate several times to remove the unreacted material and any colored impurities. The purified products were dried under vacuum and recrystallized by dissolving in either hot ethyl acetate or acetone, however, only a few of the salts could be crystallized in this way. The crystals/precipitates obtained were dried under vacuum at room temperature. TGA analysis confirmed that only salts $\mathbf{2 a}, \mathbf{9 a}$, and 11a contained any water $(\sim 2 \% \mathrm{w} / \mathrm{w})$ and this was removed from the salts by isothermal heating at 75 ${ }^{\circ} \mathrm{C}$ for $30 \mathrm{~min}$.

$N$-Methylbenzothiazolium iodide (2a). $82 \%$ yield; yellow solid; mp (visual) $221-222{ }^{\circ} \mathrm{C}$; IR (neat) 2923, 2853, 1578, 1460, 1376, $759 \mathrm{~cm}^{-1}$; ${ }^{1} \mathrm{H}$ NMR (500 MHz, CD 3 OD) 10.45 (s, 1H), 8.41 (d, J $10.0 \mathrm{~Hz}, 1 \mathrm{H}), 8.30$ (d, J $10 \mathrm{~Hz}, 1 \mathrm{H}), 7.98$ (t, J $7.5 \mathrm{~Hz}, 1 \mathrm{H}), 7.88$ (t, J $7.5 \mathrm{~Hz}, 1 \mathrm{H}), 4.50$ (s, 
$3 \mathrm{H}) ;{ }^{13} \mathrm{C}$ NMR (75 MHz, $\left.\mathrm{CD}_{3} \mathrm{OD}\right) 165.2,141.0,133.8,132.0,130.1,125.9,118.0,40.4$, HRMS calcd for cation [M-I] ${ }^{+} \mathrm{C}_{8} \mathrm{H}_{8} \mathrm{NS}$ : 150.0377 , found: 150.0372 .

$\mathrm{N}$-Ethylbenzothiazolium iodide (3a). $75 \%$ yield; yellow solid; mp (visual) $136-137{ }^{\circ} \mathrm{C}$; IR (neat) 2921, 2853, 1576, 1459, 1376, $767 \mathrm{~cm}^{-1}$; ${ }^{1} \mathrm{H}$ NMR (500 MHz, CD $\left.{ }_{3} \mathrm{OD}\right) 10.52$ (s, 1H), 8.41 (d, J $8.2 \mathrm{~Hz}, 1 \mathrm{H}$ ), 8.37 (d, J $8.6 \mathrm{~Hz}, 1 \mathrm{H}), 7.97$ (t, J $7.8 \mathrm{~Hz}, 1 \mathrm{H}$ ), 7.88 (t, J $7.7 \mathrm{~Hz}, 1 \mathrm{H}$ ), 4.90 (q, J $7.3 \mathrm{~Hz}, 2 \mathrm{H}), 1.70$ (t, 3H); ${ }^{13} \mathrm{C}$ NMR (75 MHz, CD $\left.{ }_{3} \mathrm{OD}\right) 164.5,142.0,134.0,133.0,131.3,126.2$, 118.2, 50.0, 14.5; HRMS calcd for cation [M-I] ${ }^{+} \mathrm{C}_{9} \mathrm{H}_{10} \mathrm{NS}: 164.0534$, found: 164.0538 .

$\mathrm{N}$-Propylbenzothiazolium iodide (4a). $68 \%$ yield; yellow solid; mp (visual) $158-159{ }^{\circ} \mathrm{C}$; IR (neat) 2925, 2853, 1580, 1460, 1377, $747 \mathrm{~cm}^{-1}$; ${ }^{1} \mathrm{H}$ NMR (500 MHz, CD $\left.{ }_{3} \mathrm{OD}\right) 10.60$ (s, 1H), 8.43 (d, J $8.30 \mathrm{~Hz}, 1 \mathrm{H}), 8.37$ (d, J 8.5Hz, 1H), 7.91 (s, J $7.9 \mathrm{~Hz}, 1 \mathrm{H}), 7.88$ (t, J 7.7Hz, 1H), 4.90 (t, J $7.3 \mathrm{~Hz}, 2 \mathrm{H}), 2.10$ (hex, J 7.4 Hz, 2H), 1.00 (t, J 7.4 3H); ${ }^{13} \mathrm{C}$ NMR (75 MHz, CD 3 OD) 164.0, $142.0,133.6,132.9,130.2,126.2,118.2,55.8,23.5,11.0$; HRMS calcd for cation $[\mathrm{M}-\mathrm{I}]^{+}$ $\mathrm{C}_{10} \mathrm{H}_{12} \mathrm{NS}: 178.0690$, found: 178.0687 .

$N$-Iso-propylbenzothiazolium iodide (5a). $62 \%$ yield; yellow solid; mp (DSC) $131.1{ }^{\circ} \mathrm{C}$; IR (neat) 2922, 2854, 1580, 1460, 1377, $757 \mathrm{~cm}^{-1}$; ${ }^{1} \mathrm{H}$ NMR (500 MHz, CD $3 \mathrm{OD}$ ) 10.6 (s, 1H), 8.43 (d, J $8.23 \mathrm{~Hz}, 1 \mathrm{H}$ ), 8.37 (d, J $8.54 \mathrm{~Hz}, 1 \mathrm{H}), 7.89$ (t, J 7.9Hz, 1H), 7.88 (t, J 8.0Hz, 1H), 5.50 (sep, J $6.6 \mathrm{~Hz}, 2 \mathrm{H}), 1.80$ (d, J $6.7 \mathrm{~Hz}, 6 \mathrm{H}) ;{ }^{13} \mathrm{C} \mathrm{NMR}\left(75 \mathrm{MHz}, \mathrm{CD}_{3} \mathrm{OD}\right) 131.3,130.3,126.2,118.4$, 58.0, 22.2; HRMS calcd for cation [M-I] ${ }^{+} \mathrm{C}_{10} \mathrm{H}_{12} \mathrm{NS}$ : 178.0690 , found: 178.0690 .

$\mathrm{N}$-Butylbenzothiazolium iodide (6a). $80 \%$ yield; yellow solid; mp (DSC) $116.3{ }^{\circ} \mathrm{C}$; IR (neat) 2919, 2851, 1575, 1459, 1376, $762 \mathrm{~cm}^{-1}$; ${ }^{1} \mathrm{H}$ NMR $\left(500 \mathrm{MHz}, \mathrm{CD}_{3} \mathrm{OD}\right) 10.55$ (s, 1H), 8.41 (d, J $8.26 \mathrm{~Hz}, 1 \mathrm{H}), 8.36$ (d, J $8.56 \mathrm{~Hz}, 1 \mathrm{H}), 7.98$ (t, J $7.9 \mathrm{~Hz}, 1 \mathrm{H}), 7.88$ (t, J 7.8Hz, 1H), 4.93 (t, J 7.6 Hz, 2H), 2.02 (pen, J 2.4 Hz, 2H), 1.53 (hex, J 7.7 Hz, 2H), 1.04 (t, J 7.4 Hz, 3H); ${ }^{13} \mathrm{C}$ NMR $(75$ $\left.\mathrm{MHz}, \mathrm{CD}_{3} \mathrm{OD}\right) 131.4,130.2,126.1,118.2,13.8,20.7,32.0,54.5$; HRMS calcd for cation [M-I] ${ }^{+}$ $\mathrm{C}_{11} \mathrm{H}_{14} \mathrm{NS}: 192.0848$, found: 192.0847 .

$\mathrm{N}$-Pentylbenzothiazolium iodide (7a). $79 \%$ yield; yellow solid; mp (DSC) $117.8{ }^{\circ} \mathrm{C}$; IR (neat) 2922, 2854, 1578, 1459, 1376, $767 \mathrm{~cm}^{-1}$; ${ }^{1} \mathrm{H}$ NMR $\left(500 \mathrm{MHz}, \mathrm{CD}_{3} \mathrm{OD}\right) 10.56$ (s, 1H), 8.43 (d, J $8.27 \mathrm{~Hz}, 1 \mathrm{H}), 8.37$ (d, J $8.56 \mathrm{~Hz}, 1 \mathrm{H}), 7.98$ (t, J $7.8 \mathrm{~Hz}, 1 \mathrm{H}), 7.88$ (t, J 7.8 Hz, 1H), 4.91 (t, J 7.7 Hz, 2H), 3.32 (t, J $1.2 \mathrm{~Hz}, 2 \mathrm{H}$ ), 1.41 (hex, J $3.5 \mathrm{~Hz}, 2 \mathrm{H}$ ), 2.14 (pen, J $7.5 \mathrm{~Hz}, 2 \mathrm{H}$ ), 0.93 (t, J 7.0 $\mathrm{Hz}, 3 \mathrm{H}) ;{ }^{13} \mathrm{C}$ NMR $\left(75 \mathrm{MHz}, \mathrm{CD}_{3} \mathrm{OD}\right) 164.2,141.6,132.2,131.4,130.2,126.2,118.2,54.5$, 29.8, 29.6, 23.2, 14.2; HRMS calcd for cation [M-I] $]^{+} \mathrm{C}_{12} \mathrm{H}_{16} \mathrm{NS}$ : 206.1011, found: 206.1003.

$\mathrm{N}$-Hexylbenzothiazolium iodide (8a). $77 \%$ yield; yellow solid; mp (DSC) $126.7^{\circ} \mathrm{C}$; IR (neat) 2918, 2853, 1574, 1459, 1376, $763 \mathrm{~cm}^{-1}$; ${ }^{1} \mathrm{H}$ NMR (500 MHz, CD $\left.{ }_{3} \mathrm{OD}\right)$ 10.57(s, 1H), 8.43 (d, J $8.25 \mathrm{~Hz}, 1 \mathrm{H}), 8.38$ (d, J $8.58 \mathrm{~Hz}, 1 \mathrm{H}), 7.97$ (t, J $7.7 \mathrm{~Hz}, 1 \mathrm{H}), 7.88$ (t, J $7.5 \mathrm{~Hz}, 1 \mathrm{H}), 4.95$ (t, J 7.5 $\mathrm{Hz}, 2 \mathrm{H}), 2.11(\mathrm{~m}, 2 \mathrm{H}), 1.38(\mathrm{~m}, 8 \mathrm{H}), 0.89(\mathrm{t}, \mathrm{J} 6.9 \mathrm{~Hz}, 3 \mathrm{H}) ;{ }^{13} \mathrm{C} \mathrm{NMR}\left(75 \mathrm{MHz}, \mathrm{CD}_{3} \mathrm{OD}\right) 164.2$, 141.6, 132.2, 131.4, 130.2, 126.2, 118.3, 54.6, 32.3, 30.0, 27.2, 23.5, 14.3; HRMS calcd for cation $[\mathrm{M}-\mathrm{I}]^{+} \mathrm{C}_{13} \mathrm{H}_{18} \mathrm{NS}: 220.1154$, found: 220.1160 .

$\mathrm{N}$-Heptylbenzothiazolium iodide (9a). 75\% yield; yellow solid; mp (DSC) $65.1{ }^{\circ} \mathrm{C}$; IR (neat) 2927, 2855, 1579, 1460, 1428, $762 \mathrm{~cm}^{-1}$; ${ }^{1} \mathrm{H}$ NMR (500 MHz, CD 3 OD) 10.54 (s, 1H), 8.42 (d, J $8.23 \mathrm{~Hz}, 1 \mathrm{H}), 8.37$ (d, J $8.59 \mathrm{~Hz}, 1 \mathrm{H}), 7.97$ (t, J $7.8 \mathrm{~Hz}, 1 \mathrm{H}), 7.88$ (t, J $7.6 \mathrm{~Hz}, 1 \mathrm{H}), 4.91$ (t, J 7.5 $\mathrm{Hz}, 2 \mathrm{H}), 2.11$ (pen, J $7.4 \mathrm{~Hz}, 2 \mathrm{H}), 1.39$ (m, 10H), 0.90 (t, J $6.7 \mathrm{~Hz}, 3 \mathrm{H}) ;{ }^{13} \mathrm{C} \mathrm{NMR}(75 \mathrm{MHz}$, 
$\left.\mathrm{CD}_{3} \mathrm{OD}\right) 164.2,141.8,134.0,130.2,133.0,126.2,118.2$; HRMS calcd for cation [M-I $]^{+}$ $\mathrm{C}_{14} \mathrm{H}_{20} \mathrm{NS}: 234.1313$, found: 234.1316.

N-Octylbenzothiazolium iodide (10a). 80\% yield; yellow solid; mp (DSC) $74.5{ }^{\circ} \mathrm{C}$; IR (neat) 2925, 2854, 1579, 1460, 1428, $762 \mathrm{~cm}^{-1}$; ${ }^{1} \mathrm{H}$ NMR (500 MHz, CD 3 OD) 10.54 (s, 1H), 8.42 (d, J $8.26 \mathrm{~Hz}, 1 \mathrm{H}), 8.36$ (d, J $8.55 \mathrm{~Hz}, 1 \mathrm{H}), 7.97$ (t, J 7.9 Hz, 1H), 7.88 (t, J 7.6 Hz, 1H), 4.90 (t, J 7.6 $\mathrm{Hz}, 1 \mathrm{H}), 2.10$ (pen, J $7.7 \mathrm{~Hz}, 2 \mathrm{H}), 1.39$ (m, 12H), 0.89 (t, J 7.0 Hz, 3H); ${ }^{13} \mathrm{C} \mathrm{NMR}(75 \mathrm{MHz}$, $\left.\mathrm{CD}_{3} \mathrm{OD}\right) 164.2,142.2,134.1,132.9,131.2,126.2,118.3$; HRMS calcd for cation [M-I] ${ }^{+}$ $\mathrm{C}_{15} \mathrm{H}_{22} \mathrm{NS}: 248.1477$, found: 248.1473 .

$N$-Nonylbenzothiazolium iodide (11a). $73 \%$ yield; yellow solid; mp (DSC) $82.1{ }^{\circ} \mathrm{C}$; IR (neat) 2915, 2849, 1574, 1458, 1428, $762 \mathrm{~cm}^{-1}$; ${ }^{1} \mathrm{H}$ NMR (500 MHz, CD 3 OD) 10.55 (s, 1H), 8.43 (d, J $8.27 \mathrm{~Hz}, 1 \mathrm{H}), 8.37$ (d, J $8.56 \mathrm{~Hz}, 1 \mathrm{H}), 7.98$ (t, J $7.8 \mathrm{~Hz}, 1 \mathrm{H}), 7.88$ (t, J $7.7 \mathrm{~Hz}, 1 \mathrm{H}), 4.38$ (t, J 7.5 $\mathrm{Hz}, 2 \mathrm{H}), 2.01$ (pen, J $7.4 \mathrm{~Hz}, 2 \mathrm{H}), 1.35$ (m, 14H), 0.95 (t, J $6.8 \mathrm{~Hz}, 3 \mathrm{H}) ;{ }^{13} \mathrm{C} \mathrm{NMR}(75 \mathrm{MHz}$, $\left.\mathrm{CD}_{3} \mathrm{OD}\right) 164.0,142.6,134.5,130.3,131.3,126.1,118.2$; HRMS calcd for cation [M-I] ${ }^{+}$ $\mathrm{C}_{16} \mathrm{H}_{24} \mathrm{NS}: 262.1629$; found: 262.1629.

$N$-Decylbenzothiazolium iodide (12a). $70 \%$ yield; yellow solid; mp (DSC) $82.4{ }^{\circ} \mathrm{C}$; IR (neat) 2916, 2852, 1576, 1460, 1376, $758 \mathrm{~cm}^{-1}$; ${ }^{1} \mathrm{H}$ NMR (500 MHz, CD 3 OD) 10.56 (s, 1H), 8.43 (d, J $8.28 \mathrm{~Hz}, 1 \mathrm{H}), 8.35$ (d, J $8.56 \mathrm{~Hz}, 1 \mathrm{H}), 7.97$ (t, J $7.8 \mathrm{~Hz}, 1 \mathrm{H}), 7.88$ (t, J $7.88 \mathrm{~Hz}, 1 \mathrm{H}), 4.39$ (t, J 7.5 $\mathrm{Hz}, 2 \mathrm{H}), 2.11$ (pen, J $7.0 \mathrm{~Hz}, 2 \mathrm{H}), 1.75(\mathrm{~m}, 16 \mathrm{H}), 0.9(\mathrm{t}, \mathrm{J} 6.3 \mathrm{~Hz}, 3 \mathrm{H}) ;{ }^{13} \mathrm{C} \mathrm{NMR}(75 \mathrm{MHz}$, $\left.\mathrm{CD}_{3} \mathrm{OD}\right) 164.2,142.0,133.8,126.2,130.2$, 131.3, 118.2, 14.4, 23.7, 27.4, 30.0, 30.1, 30.4, 30.5, 30.6, 33.0, 54.4; HRMS calcd for cation [M-I] ${ }^{+} \mathrm{C}_{17} \mathrm{H}_{26} \mathrm{NS}: 276.1786$, found: 276.1782 .

$\mathrm{N}$-Undecylbenzothiazolium iodide (13a). $75 \%$ yield; yellow solid; mp (DSC) $80.4{ }^{\circ} \mathrm{C}$; IR (neat) 2922, 2853, 1580, 1460, 1376, $758 \mathrm{~cm}^{-1}$; ${ }^{1} \mathrm{H}$ NMR (500 MHz, CD 3 OD) 10.55 (s, 1H), 8.43 (d, J $8.26 \mathrm{~Hz}, 1 \mathrm{H}), 8.37$ (d, J $8.56 \mathrm{~Hz}, 1 \mathrm{H}), 7.97$ (t, J 7.9 Hz, 1H), 7.88 (t, J 7.8 Hz, 1H), 4.89 (t, J 7.4 $\mathrm{Hz}, 2 \mathrm{H}), 2.11$ (pen, J $7.4 \mathrm{~Hz}, 2 \mathrm{H}), 1.40$ (m, 18H), 0.90 (t, J $6.7 \mathrm{~Hz}, 3 \mathrm{H}) ;{ }^{13} \mathrm{C} \mathrm{NMR}(75 \mathrm{MHz}$, $\left.\mathrm{CD}_{3} \mathrm{OD}\right) 164.0,142.6,132.8,130.2,131.3,126.2,118.2$; HRMS calcd for cation $[\mathrm{M}-\mathrm{I}]^{+}$ $\mathrm{C}_{18} \mathrm{H}_{28} \mathrm{NS}: 290.1942$, found: 290.1943.

$N$-Dodecylbenzothiazolium iodide (14a). $72 \%$ yield; yellow solid; mp (DSC) $90.5{ }^{\circ} \mathrm{C}$; IR (neat) 2924, 2852, 1578, 1461, 1376, $759 \mathrm{~cm}^{-1}$; ${ }^{1} \mathrm{H}$ NMR (500 MHz, CD $\left.{ }_{3} \mathrm{OD}\right) 10.53$ (s, 1H), 8.42 (t, J $8.23 \mathrm{~Hz}, 1 \mathrm{H}), 7.98$ (t, J $7.8 \mathrm{~Hz}, 1 \mathrm{H}), 7.89$ (t, J $7.6 \mathrm{~Hz}, 1 \mathrm{H}), 4.39$ (t, J 7.4 Hz, 2H), 2.11 (pen, J 7.4 $\mathrm{Hz}, 2 \mathrm{H}), 1.40(\mathrm{~m}, 20 \mathrm{H}), 0.88$ (t, J $6.7 \mathrm{~Hz}, 3 \mathrm{H}) ;{ }^{13} \mathrm{C} \mathrm{NMR}\left(75 \mathrm{MHz}, \mathrm{CD}_{3} \mathrm{OD}\right)$ 164.2, 141.8, 132.9, 131.4, 130.2, 126.2, 118.3, 54.6, 33.0, 30.6, 30.4, 30.2, 30.1, 30.0, 27.5, 23.7, 14.4; HRMS calcd for cation [M-I] ${ }^{+} \mathrm{C}_{19} \mathrm{H}_{30} \mathrm{NS}$ : 304.2099, found: 304.2097.

\section{Metathesis reactions}

The anion exchange of the prepared quaternary benzothiazolium iodide salts was carried using the following protocol: $1 \mathrm{~g}$ of compound, $10 \mathrm{~mL}$ of acetone and an equivalent amount of the anion salt $\left(\mathrm{Li}\left[\mathrm{NTf}_{2}\right]\right.$ or $\left.\mathrm{Na}\left[\mathrm{CF}_{3} \mathrm{SO}_{3}\right]\right)$ were added followed by stirring at room temperature for 4 to $6 \mathrm{~h}$. After successful anion exchange and purification of the compound by drying, the compounds were extracted with anhydrous ethyl acetate (absolute ethanol where necessary) and 
the new salts isolated. Completion of the purification step was monitored by silver nitrate halide tests. The anion exchange reactions gave the desired products in yields above $80 \%$.

$\boldsymbol{N}$-Methylbenzothiazolium bistrifluoromethanesulfonimide (2b). Brown Solid; mp (DSC) $79.0^{\circ} \mathrm{C}$; IR (neat), 3124, 3093, 2329, 1466, 1342, 1175, 1130, 1051, $768 \mathrm{~cm}^{-1}$; ${ }^{1} \mathrm{H}$ NMR (500 $\left.\mathrm{MHz}, \mathrm{CD}_{3} \mathrm{OD}\right) 10.40$ (s, 1H), 8.40 (d, J $\left.8.5 \mathrm{~Hz}, 1 \mathrm{H}\right), 8.29$ (d, J $\left.8.5 \mathrm{~Hz}, 1 \mathrm{H}\right), 7.98$ (t, J $8.5 \mathrm{~Hz}$, 1H), 7.89 (t, J $8.25 \mathrm{~Hz}, 1 \mathrm{H}), 4.46$ (s, 3H); ${ }^{13} \mathrm{C}$ NMR (125 MHz, CD $\left.{ }_{3} \mathrm{OD}\right)$ 165.2, 131.6, 130.4, 126.1, 122.8, 120.2, 118.2, 40.4; HRMS (EI) calcd for cation [M-NTf $]^{+} \mathrm{C}_{8} \mathrm{H}_{8} \mathrm{NS}$ : 150.0534, found: 150.0377 .

$\boldsymbol{N}$-Ethylbenzothiazolium bistrifluoromethanesulfonimide (3b). Yellow Solid; mp (DSC) 66.2 ${ }^{\circ} \mathrm{C}$; IR (neat) 3109, 1580, 1512, 1433, 1342, 1180, 1130, 1049, 892, 783, 758, $735 \mathrm{~cm}^{-1}$; ${ }^{1} \mathrm{H}$ NMR (500 MHz, CD 3 OD) $10.46(\mathrm{~s}, 1 \mathrm{H}), 8.41$ (d, J $8.0 \mathrm{~Hz} 1 \mathrm{H}), 8.35$ (d, J 9.0 Hz 1H), 7.98 (t, J 8.5Hz, 1H), 7.89 (s, J $8.25 \mathrm{~Hz}, 1 \mathrm{H}), 4.90$ (t, J $7.25 \mathrm{~Hz}, 3 \mathrm{H}), 1.74$ (t, J 7.5 Hz, 3H); ${ }^{13} \mathrm{C}$ NMR (125 MHz, $\left.\mathrm{CD}_{3} \mathrm{OD}\right) 165.3,131.9,130.8,126.5,123.0,120.5,118.6,109.7,50.4,14.9$; HRMS (EI) calcd for cation $\left[\mathrm{M}-\mathrm{NTf}_{2}\right]^{+} \mathrm{C}_{9} \mathrm{H}_{10} \mathrm{NS}: 164.0534$, found: 164.0529 .

$\boldsymbol{N}$-Propylbenzothiazolium bistrifluoromethanesulfonimide (4b). Yellow Solid; mp (DSC) $69.3{ }^{\circ} \mathrm{C}$; IR (neat) 3098, 2982, 1580, 1509, 1456, 1433, 1342, 1180, 1132, 1046, 786, 761, 735. $\mathrm{cm}^{-1}$; ${ }^{1} \mathrm{H}$ NMR (500 MHz, CD $\left.3 \mathrm{OD}\right) 10.47$ (s, 1H), 8.41 (d, J $\left.10.0 \mathrm{~Hz}, 1 \mathrm{H}\right), 8.36$ (d, J 8.5 Hz, 1H), 7.98 (t, J $8.50 \mathrm{~Hz}, 1 \mathrm{H}), 7.89$ (t, J $8.25 \mathrm{~Hz}, 1 \mathrm{H}), 4.84$ (t, J $7.5 \mathrm{~Hz} 2 \mathrm{H}), 1.08$ (t, J 7.5 Hz, 3H); ${ }^{13} \mathrm{C}$ NMR (125 MHz, CD 3 OD) 157.9, 133.7, 132.1, 130.9, 126.7, 120.6, 118.8; HRMS (EI) calcd for cation [M-NTf $]^{+} \mathrm{C}_{10} \mathrm{H}_{12} \mathrm{NS}: 178.2750$, found: 178.2750 .

$\boldsymbol{N}$-Iso-propylbenzothiazolium bistrifluoromethanesulfonimide (5b). Yellow Solid; mp (DSC) $88.3{ }^{\circ} \mathrm{C}$; IR (neat) $3118,2997,1578,1507,1461,1342,1178,1127,1044,905,786,738,758$ $\mathrm{cm}^{-1}$; ${ }^{1} \mathrm{H}$ NMR (500 MHz, CD $\left.3 \mathrm{OD}\right) 10.50$ (s, 1H), 8.42 (t, J 7.5 Hz, 2H), 8.40 (t, J 8.5 Hz, 1H), 7.89 (t, J $8.25 \mathrm{~Hz}, 1 \mathrm{H}), 5.46(\mathrm{~m}, 1 \mathrm{H}), 1.81$ (d, J $6.5 \mathrm{~Hz}, 6 \mathrm{H}) ;{ }^{13} \mathrm{C}$ NMR $\left(125 \mathrm{MHz}, \mathrm{CD}_{3} \mathrm{OD}\right)$ $163.8,132.0,131.0,126.8,123.2,120.7,119.0$, 58.7, 22.7; HRMS (EI) calcd for cation [M$\left.\mathrm{NTf}_{2}\right]^{+} \mathrm{C}_{10} \mathrm{H}_{12} \mathrm{NS}: 178.2750$, found: 178.2750.

$N$-Butylbenzothiazolium bistrifluoromethanesulfonimide (6b). Yellow Solid; mp (DSC) 60.6 ${ }^{\circ} \mathrm{C}$; IR (neat) 3068, 2962, 2870, 1580, 1507, 1431, 1461, 1325, 1345, 1228, 1175, 1122, 1054, 875, 783, 763, 731, $\mathrm{cm}^{-1}$; ${ }^{1} \mathrm{H}$ NMR (500 MHz, CD $\left.3 \mathrm{OD}\right) 10.47$ (s, 1H), 8.41 (d, J 8.0 Hz, 1H), 8.36 (d, J 9.0Hz, 1H), 7.99 (t, J $8.5 \mathrm{~Hz}, 1 \mathrm{H}), 7.89$ (t, J $8.0 \mathrm{~Hz}, 1 \mathrm{H}), 4.86$ (t, J 7.5 Hz, 2H), 2.07 (m, 2H), 1.50 (m, 2H), 1.04 (t, J 7.5 Hz, 3H); ${ }^{13} \mathrm{C}$ NMR (125 MHz, CD 3 OD) 165.2, 131.6, 129.9, 128.8, 124.7, 122.3, 116.7, 52.9, 30.6, 19.3, 12.3; HRMS (EI) calcd for cation [M-NTf $]^{+}$ $\mathrm{C}_{11} \mathrm{H}_{14} \mathrm{NS}: 192.3020$, found: 192.3020 .

$N$-Pentylbenzothiazolium bistrifluoromethanesulfonimide (7b). Yellow Solid; mp (DSC) $49.3{ }^{\circ} \mathrm{C}$; IR (neat) 3068, 2931, 2855, 1578, 1504, 1461, 1428, 1342, 1325, 1180, 1125, 1054, 867, 783, 763, $735 \mathrm{~cm}^{-1}$; ${ }^{1} \mathrm{H}$ NMR (500 MHz, CD $\left.3 \mathrm{OD}\right) 10.48$ (s, 1H), 8.42 (d, J $\left.8.5 \mathrm{~Hz}, 1 \mathrm{H}\right), 8.36$ (d, J $8.5 \mathrm{~Hz}, 1 \mathrm{H}), 7.98$ (t, J $8.25 \mathrm{~Hz}, 1 \mathrm{H}), 7.88$ (t, J $8.0 \mathrm{~Hz}, 1 \mathrm{H}), 4.86$ (t, J $7.5 \mathrm{~Hz}, 2 \mathrm{H}), 2.11$ (m, 2H), $1.44(\mathrm{~m}, 4 \mathrm{H}), 0.95$ (t, J 7.0 Hz, 3H); ${ }^{13} \mathrm{C}$ NMR (125 MHz, CD 3 OD) 163.5, 131.3, 130.1, 126.0, 120.8, 120.2, 118.1, 54.4, 29.7, 29.4, 23.0, 14.0; HRMS (EI) calcd for cation [M-NTf $]^{+}$ $\mathrm{C}_{12} \mathrm{H}_{16} \mathrm{NS}: 206.3280$, found: 206.3280 . 
$\boldsymbol{N}$-Hexylbenzothiazolium bistrifluoromethanesulfonimide (8b). Yellow Solid; mp (DSC) 48.9 ${ }^{\circ} \mathrm{C}$; IR (neat) 3114, 2926, 2850, 1580, 1507, 1431, 1340, 1317, 1188, 1125, 1049, 786, 766, 738, $\mathrm{cm}^{-1}$; ${ }^{1} \mathrm{H}$ NMR (500 MHz, CD $\left.3 \mathrm{OD}\right) 10.44$ (s, 1H), 8.38 (d, J $\left.8.5 \mathrm{~Hz}, 1 \mathrm{H}\right), 8.33$ (d, J 8.5 Hz, 1H), 7.95 (t, J $8.25 \mathrm{~Hz}, 1 \mathrm{H}), 7.85$ (t, J $7.75 \mathrm{~Hz}, 1 \mathrm{H}), 4.83$ (t, J 7.5 Hz, 2H), 2.05 (m, 2H), 1.47-1.21 $(\mathrm{m}, 6 \mathrm{H}), 0.89$ (t, J $7.0 \mathrm{~Hz}, 3 \mathrm{H}) ;{ }^{13} \mathrm{C} \mathrm{NMR}\left(125 \mathrm{MHz}, \mathrm{CD}_{3} \mathrm{OD}\right)$ 163.9, 132.9, 131.3, 130.1, 125.9, 122.4, 118.0, 54.4, 32.2, 29.9, 27.0, 23.3, 14.1; HRMS (EI) calcd for cation [M-NTf $]^{+}$ $\mathrm{C}_{13} \mathrm{H}_{18} \mathrm{NS}: 220.3550$, found: 220.3550 .

$\boldsymbol{N}$-Heptylbenzothiazolium bistrifluoromethanesulfonimide (9b). Yellow Solid; mp (DSC) $39.6^{\circ} \mathrm{C}$; IR (neat) 3083, 2931, 2860, 1580, 1509, 1464, 1431, 1347, 1183, 1132, 1044, 897, 789, 758, $730 \mathrm{~cm}^{-1}$; ${ }^{1} \mathrm{H}$ NMR (500 MHz, CD $\left.3 \mathrm{OD}\right) 10.47$ (s, 1H), 8.41 (d, J $\left.8.0 \mathrm{~Hz}, 1 \mathrm{H}\right), 8.35$ (d, J 8.5 $\mathrm{Hz}, 1 \mathrm{H}), 7.99$ (t, J $7.75 \mathrm{~Hz}, 1 \mathrm{H}), 7.88$ (t, J $7.75 \mathrm{~Hz}, 1 \mathrm{H}), 4.85$ (t, J $7.6 \mathrm{~Hz}, 2 \mathrm{H}), 2.09$ (m, 2H),1.49-1.29 (m, 8H), 0.89 (t, J 7.0 Hz, 3H); ${ }^{13} \mathrm{C} \mathrm{NMR}\left(125 \mathrm{MHz}, \mathrm{CD}_{3} \mathrm{OD}\right)$ 163.8, 132.8, 131.2, 130.0, 125.8, 117.9, 108.9, 54.3, 32.5, 29.8, 29.5, 27.2, 23.3, 14.1; HRMS (EI) calcd for cation [M-NTf $]^{+} \mathrm{C}_{14} \mathrm{H}_{20} \mathrm{NS}$ : 234.3810, found: 234.3810 .

N-Octylbenzothiazolium bistrifluoromethanesulfonimide (10b). Yellow Solid; mp (DSC) $46.9{ }^{\circ} \mathrm{C}$; IR (neat) 3073, 2926, 2855, 1582, 1509, 1458, 1431, 1347, 1327, 1178, 1125, 1052, 864, 781, 766, $733 \mathrm{~cm}^{-1}$; ${ }^{1} \mathrm{H}$ NMR (500 MHz, CD $\left.3 \mathrm{OD}\right) 10.46$ (s, 1H), 8.41 (d, J $\left.8.0 \mathrm{~Hz}, 1 \mathrm{H}\right), 8.35$ (d, J $8.5 \mathrm{~Hz}, 1 \mathrm{H}), 7.98$ (t, J $8.5 \mathrm{~Hz}, 1 \mathrm{H}), 7.89$ (t, J $8.5 \mathrm{~Hz}, 1 \mathrm{H}), 4.86$ (t, J $7.5 \mathrm{~Hz}, 2 \mathrm{H}), 2.09$ (m, $2 \mathrm{H}), 1.49-1.28(\mathrm{~m}, 10 \mathrm{H}), 0.89(\mathrm{t}, \mathrm{J} 7.0 \mathrm{~Hz}, 3 \mathrm{H}) ;{ }^{13} \mathrm{C} \mathrm{NMR}\left(125 \mathrm{MHz}, \mathrm{CD}_{3} \mathrm{OD}\right)$ 163.9, 132.5, 130.9, 129.7, 125.5, 122.0, 119.4, 117.6, 54.0, 32.3, 29.7, 29.57, 29.5, 26.9, 23.1, 13.9; HRMS (EI) calcd for cation [M-NTf $]^{+} \mathrm{C}_{15} \mathrm{H}_{22} \mathrm{NS}$ : 248.4080, found: 248.4080.

$\boldsymbol{N}$-Nonylbenzothiazolium bistrifluoromethanesulfonimide (11b). Yellow Solid; mp (DSC) $46.3{ }^{\circ} \mathrm{C}$; IR (neat) 3108, 2946, 2870, 1580, 1504, 1454, 1436, 1342, 1319, 1180, 1127, 1059, 783, 763, $730 \mathrm{~cm}^{-1} ;{ }^{1} \mathrm{H}$ NMR (500 MHz, CD $\left.3 \mathrm{OD}\right) 10.47$ (s, 1H), 8.41 (d, J $\left.8.5 \mathrm{~Hz}, 1 \mathrm{H}\right), 8.36$ (d, J $8.5 \mathrm{~Hz}, 1 \mathrm{H}), 7.88$ (t, J $8.25 \mathrm{~Hz}, 1 \mathrm{H}), 4.85$ (t, J $7.5 \mathrm{~Hz}, 3 \mathrm{H}), 2.09$ (m, 2H), 1.49-1.28 (m, 12H), 0.88 (t, J $6.7 \mathrm{~Hz}, 3 \mathrm{H}) ;{ }^{13} \mathrm{C} \mathrm{NMR}\left(125 \mathrm{MHz}, \mathrm{CD}_{3} \mathrm{OD}\right)$ 164.0, 131.3, 130.1, 126.0, 122.4, 120.2, 118.0, 54.4, 32.8, 30.3, 30.2, 30.0, 29.9, 27.3, 23.6, 14.3; HRMS (EI) calcd for cation [M-NTf $]^{+}$ $\mathrm{C}_{16} \mathrm{H}_{24} \mathrm{NS}: 262.4350$; found: 262.4350 .

$N$-Decylbenzothiazolium bistrifluoromethanesulfonimide (12b). Yellow Solid; mp (DSC) $49.5{ }^{\circ} \mathrm{C}$; IR (neat) 3068, 2921, 2850, 1580, 1507, 1461, 1431, 1347, 1327, 1178, 1127, 1054, 783, 766, $730 \mathrm{~cm}^{-1}$; ${ }^{1} \mathrm{H}$ NMR (500 MHz, CD $\left.3 \mathrm{OD}\right) 10.47$ (s, 1H), 8.41 (d, J $\left.8.5 \mathrm{~Hz}, 1 \mathrm{H}\right), 8.36$ (d, J $8.5 \mathrm{~Hz}, 1 \mathrm{H}), 7.99$ (t, J 8.5,Hz 1H), 7.89 (t, J $8.25 \mathrm{~Hz}, 1 \mathrm{H}), 4.86$ (t, J 7.0 Hz, 2H), 2.08 (m, 2H), 1.46-1.28 (m, 14H), 0.88 (t, J 7.0 Hz, 3H); ${ }^{13} \mathrm{C}$ NMR (125 MHz, CD $\left.{ }_{3} \mathrm{OD}\right)$ 162.8, 132.2, 131.1, 126.9, 121.7, 120.3, 119.0, 55.3, 33.9, 31.4, 31.3, 31.2, 30.9, 28.3, 24.6, 15.3; HRMS (EI) calcd for cation [M-NTf $]^{+} \mathrm{C}_{17} \mathrm{H}_{26} \mathrm{NS}$ : 276.4610, found: 276.4610 .

$\mathrm{N}$-Undecylbenzothiazolium bistrifluoromethanesulfonimide (13b). Yellow Solid; mp (DSC) $44.2{ }^{\circ} \mathrm{C}$; IR (neat) 3068, 2926, 2855, 1577, 1507, 1464, 1428, 1342, 1327, 1178, 1127, 1054 , 872, 783, 763, $733 \mathrm{~cm}^{-1}$; ${ }^{1} \mathrm{H}$ NMR (500 MHz, CD $\left.3 \mathrm{OD}\right) 10.46$ (s, 1H), 8.40 (d, J $\left.8.5 \mathrm{~Hz}, 1 \mathrm{H}\right), 8.35$ (d, J $8.5 \mathrm{~Hz}, 1 \mathrm{H}), 7.97$ (t, J $8.0 \mathrm{~Hz}, 1 \mathrm{H}), 7.88$ (t, J $7.75 \mathrm{~Hz}, 1 \mathrm{H}), 4.85$ (t, J $7.5 \mathrm{~Hz}, 3 \mathrm{H}), 2.09$ (m, 2H), 1.48-1.27 (t, J 6.25 Hz, 3H); ${ }^{13} \mathrm{C}$ NMR (125 MHz, CD $\left.3 \mathrm{OD}\right)$ 163.8, 131.3, 130.1, 125.9, 
122.7, 120.5, 118.1, 54.4, 32.9, 30.5, 30.4, 30.3, 29.9, 27.3, 23.6, 14.3; HRMS (EI) calcd for cation [M-NTf $]^{+} \mathrm{C}_{18} \mathrm{H}_{28} \mathrm{NS}: 290.4880$, found: 290.4880 .

$\boldsymbol{N}$-Dodecylbenzothiazolium bistrifluoromethanesulfonimide (14b). Yellow Solid; mp (DSC) $49.9^{\circ} \mathrm{C}$; IR (neat) 3053, 2926, 2850, 1580, 1507, 1431, 1458, 1342, 1325, 1175, 1127, 1054, 872, 768, 730. $\mathrm{cm}^{-1} ;{ }^{1} \mathrm{H} \mathrm{NMR}\left(500 \mathrm{MHz}, \mathrm{CD}_{3} \mathrm{OD}\right) 10.48$ (s, 1H), 8.43 (d, J $\left.8.5 \mathrm{~Hz}, 1 \mathrm{H}\right), 8.38$ (d, J $8.5 \mathrm{~Hz}, 1 \mathrm{H}), 8.00$ (t, J $8.0 \mathrm{~Hz}, 1 \mathrm{H}), 7.91$ (t, J $7.75 \mathrm{~Hz}, 1 \mathrm{H}), 4.87$ (t, J $7.5 \mathrm{~Hz}, 3 \mathrm{H}), 2.11$ (m, 2H), 1.51-1.30 (m, 18H), 0.91 (t, J 6.5 Hz, 3H); ${ }^{13} \mathrm{C}$ NMR (125 MHz, CD $\left.{ }_{3} \mathrm{OD}\right)$ 163.2, 131.9, 130.7, 126.5, 122.2, 120.4, 118.6, 55.0, 33.5, 31.1, 31.0, 30.9, 30.5, 30.5, 27.9, 24.1, 14.8; HRMS (EI) calcd for cation [M-NTf $]^{+} \mathrm{C}_{19} \mathrm{H}_{30} \mathrm{NS}$ : 304.5140, found: 304.5140 .

$N$-Methylbenzothiazolium trifluoromethylsulfonate (2c). Brown Solid; mp (visual) 191-192 ${ }^{\circ} \mathrm{C}$; IR (neat) 2997, 1575, 1517, 1431, 1398, 1251, 1163,1122, 1029, 953, 882, $758 \mathrm{~cm}^{-1} ;{ }^{1} \mathrm{H}$ NMR (500 MHz, CD 3 OD) 10.45 (s, 1H), 8.42 (d, J 8.19 Hz, 1H), 8.31 (d, J 8.82 Hz, 1H), 7.99 (t, J $8.19 \mathrm{~Hz}, 1 \mathrm{H}), 7.90$ (t, J $7.88 \mathrm{~Hz}, 1 \mathrm{H}), 4.47$ (s, 3H); ${ }^{13} \mathrm{C}$ NMR (125 MHz, CD $\left.{ }_{3} \mathrm{OD}\right)$ 163.4, 141.2, 132.0, 130.8, 126.5, 122.3, 120.1, 118.7, 41.0; HRMS (EI) calcd for cation $\left[\mathrm{M}-\mathrm{CF}_{3} \mathrm{SO}_{3}\right]^{+}$ $\mathrm{C}_{8} \mathrm{H}_{8} \mathrm{NS}: 150.0377$, found: 150.0377 .

$\boldsymbol{N}$-Ethylbenzothiazolium trifluoromethylsulfonate (3c). Yellow Solid; mp (DSC) $126.5{ }^{\circ} \mathrm{C}$; IR (neat) 3073, 3043, 2916, 1580,1514, 1458, 1439, 1388, 1307, 1259, 1191, 1153, 1024, 958, 892, 839, $753 \mathrm{~cm}^{-1}$; ${ }^{1} \mathrm{H}$ NMR (500 MHz, CD $\left.3 \mathrm{OD}\right) 10.55$ (s, 1H), 8.44 (d, J $\left.8.35 \mathrm{~Hz}, 1 \mathrm{H}\right), 8.38$ (d, J $8.51 \mathrm{~Hz}, 1 \mathrm{H}), 7.98$ (t, J $7.88 \mathrm{~Hz}, 1 \mathrm{H}), 7.88$ (t, J $7.82 \mathrm{~Hz}, 1 \mathrm{H}), 4.93$ (m, 2H), 1.75 (t, J $7.4 \mathrm{~Hz}$, $3 \mathrm{H}) ;{ }^{13} \mathrm{C}$ NMR $\left(125 \mathrm{MHz}, \mathrm{CD}_{3} \mathrm{OD}\right) 164.5,142.0,132.5,130.9,129.7,125.6,122.4,120.3$, 117.7, 108.7, 49.5, 14.0; HRMS (EI) calcd for cation $\left[\mathrm{M}-\mathrm{CF}_{3} \mathrm{SO}_{3}\right]^{+} \mathrm{C}_{9} \mathrm{H}_{10} \mathrm{NS}$ : 164.0534 , found: 164.0529 .

N-Propylbenzothiazolium trifluoromethylsulfonate (4c). Yellow Solid; mp (DSC) $124.1{ }^{\circ} \mathrm{C}$; IR (neat) 3043, 2997, 2962, 1580, 1512, 1458, 1431, 1385, 1342, 1251, 1218, 1153, 1026, 857, 794, $756 \mathrm{~cm}^{-1}$; ${ }^{1} \mathrm{H}$ NMR (500 MHz, CD $\left.3 \mathrm{OD}\right) 10.54$ (s, 1H), 8.44 (d, J $\left.8.22 \mathrm{~Hz}, 1 \mathrm{H}\right), 8.39$ (t, J $8.41 \mathrm{~Hz}, 1 \mathrm{H}), 7.99$ (t, J $7.90 \mathrm{~Hz}, 1 \mathrm{H}), 7.88$ (t, J $7.79 \mathrm{~Hz}, 1 \mathrm{H}), 4.87$ (t, J 7.5 Hz, 3H), 2.17-2.10 (m, 2H), 1.08 (s, J 7.4 Hz, 3H); ${ }^{13} \mathrm{C}$ NMR (125 MHz, CD 3 OD) 163.7, 141.0, 132.9, 131.3, 130.1, 126.0, 122.0, 118.1, 55.8, 23.5, 10.9; HRMS (EI) calcd for cation $\left[\mathrm{M}-\mathrm{CF}_{3} \mathrm{SO}_{3}\right]^{+} \mathrm{C}_{10} \mathrm{H}_{12} \mathrm{NS}$ : 178.0690, found: 178.0685 .

$\boldsymbol{N}$-Iso-propylbenzothiazolium trifluoromethylsulfonate (5c). Yellow Solid; mp (DSC) 118.3 ${ }^{\circ} \mathrm{C}$; IR (neat) 3022, 2992, 2967, 1577, 1507, 1436, 1375, 1309, 1264, 1249, 1163, 1117, 1021, 905, 849,756, $730 \mathrm{~cm}^{-1}$; ${ }^{1} \mathrm{H}$ NMR (500 MHz, CD $\left.3 \mathrm{OD}\right) 10.59$ (s, 1H), 8.45 (t, J 7.7 Hz, 2H), 7.99 (t, J $8.5 \mathrm{~Hz}, 1 \mathrm{H}), 7.89$ (t, J $8.25 \mathrm{~Hz}, 1 \mathrm{H}), 5.49$ (m, 1H), 1.82 (d, J $6.5 \mathrm{~Hz}, 6 \mathrm{H}) ;{ }^{13} \mathrm{C}$ NMR $(125$ $\left.\mathrm{MHz}, \mathrm{CD}_{3} \mathrm{OD}\right) 162.6,141.8,133.4,131.7,130.6,126.5,122.3,118.7,58.4,22.5$; HRMS (EI) calcd for cation $\left[\mathrm{M}-\mathrm{CF}_{3} \mathrm{SO}_{3}\right]^{+} \mathrm{C}_{10} \mathrm{H}_{12} \mathrm{NS}$ : 178.0686 , found: 178.0690 .

$N$-Butylbenzothiazolium trifluoromethylsulfonate (6c). Yellow Solid; mp (DSC) $106.1{ }^{\circ} \mathrm{C}$; IR (neat) 3068, 2977, 2951, 1719, 1580, 1514, 1453, 1319, 1249, 1155, 1024, 902, $761 \mathrm{~cm}^{-1} ;{ }^{1} \mathrm{H}$ NMR (500 MHz, CD 3 OD) 10.57 (s, 1H), 8.45 (d, J 8.19 Hz, 1H), 8.39 (d, J 8.5 Hz, 1H), 7.98 (t, J $8.25 \mathrm{~Hz}, 1 \mathrm{H}), 7.89$ (t, J $8.25 \mathrm{~Hz}, 1 \mathrm{H}), 4.90$ (t, J $7.5 \mathrm{~Hz}, 2 \mathrm{H}), 2.09$ (m, 2H), 1.51 (m, 2H), 1.03 (t, J $7.25 \mathrm{~Hz}, 3 \mathrm{H}) ;{ }^{13} \mathrm{C}$ NMR (125 MHz, CD $\left.3 \mathrm{OD}\right)$ 162.3, 141.5, 132.8, 131.3, 130.1, 126.1, 118.2, 
54.2, 31.9, 20.7, 13.7; HRMS (EI) calcd for cation $\left[\mathrm{M}-\mathrm{CF}_{3} \mathrm{SO}_{3}\right]^{+} \mathrm{C}_{11} \mathrm{H}_{14} \mathrm{NS}$ : 192.0847 , found: 192.0842 .

$\mathrm{N}$-Pentylbenzothiazolium trifluoromethylsulfonate (7c). Yellow Solid; mp (DSC) $80.5{ }^{\circ} \mathrm{C}$; IR (neat) 3068, 2946, 2855, 1673, 1577, 1507, 1458, 1423, 1241, 1148, 1029, 887, 796, 761, 720 $\mathrm{cm}^{-1}$; ${ }^{1} \mathrm{H}$ NMR (500 MHz, CD $\left.3 \mathrm{OD}\right) 10.58$ (s, 1H), 8.45 (d, J 9.0 Hz, 1H), 8.40 (d, J 8.5 Hz, 1H), 7.98 (t, J $8.5 \mathrm{~Hz}, 1 \mathrm{H}), 7.88$ (t, J $8.25 \mathrm{~Hz}, 1 \mathrm{H}), 4.91$ (t, J $7.5 \mathrm{~Hz}, 2 \mathrm{H}), 2.11(\mathrm{~m}, 2 \mathrm{H}), 1.45$ (m, 4H), 0.94 (t, J 7.25 Hz, 3H); ${ }^{13} \mathrm{C}$ NMR (125 MHz, CD $\left.3 \mathrm{OD}\right)$ 163.0, 142.1, 133.2, 131.7, 130.5, 126.5, 118.6, 54.8, 30.1, 29.1, 23.5, 14.5; HRMS (EI) calcd for cation $\left[\mathrm{M}-\mathrm{CF}_{3} \mathrm{SO}_{3}\right]^{+} \mathrm{C}_{12} \mathrm{H}_{16} \mathrm{NS}$ : 206.1003, found: 206.1010 .

$\boldsymbol{N}$-Hexylbenzothiazolium trifluoromethylsulfonate (8c). Yellow Solid; mp (DSC) $74.0{ }^{\circ} \mathrm{C}$; IR (neat) $3017,2916,2845,1575,1494,1458,1421,1221,1257,1140,1024,864,758 \mathrm{~cm}^{-1} ;{ }^{1} \mathrm{H}$ NMR (500 MHz, CD 3 OD) 10.57 (s, 1H), 8.45 (d, J 9.0 Hz, 1H), 8.39 (d, J 8.5 Hz, 1H), 7.99 (t, J $8.5 \mathrm{~Hz}, 1 \mathrm{H}), 7.89$ (t, J $8.25 \mathrm{~Hz}, 1 \mathrm{H}), 4.89$ (t, J 7.5 Hz, 2H), 2.11 (m, 2H), 1.52-1.28 (m, 6H), 0.92 (t, J 7.25 Hz, 3H); ${ }^{13} \mathrm{C}$ NMR (125 MHz, CD $\left.\mathrm{OD}\right)$ 163.2, 141.7, 132.8, 131.3, 130.1, 126.1, 118.2, 109.0, 54.5, 32.2, 29.9, 27.0, 23.4, 14.2; HRMS (EI) calcd for cation $\left[\mathrm{M}-\mathrm{CF}_{3} \mathrm{SO}_{3}\right]^{+} \mathrm{C}_{13} \mathrm{H}_{18} \mathrm{NS}$ : 220.1160, found: 220.1156.

$N$-Heptylbenzothiazolium trifluoromethylsulfonate (9c). Yellow Solid; mp (DSC) $58.9{ }^{\circ} \mathrm{C}$; IR (neat) $3043,2916,2855,1577,1501,1456,1426,1213,1160,1029,885,761, \mathrm{~cm}^{-1}$; ${ }^{1} \mathrm{H}$ NMR (500 MHz, CD 3 OD) 10.55 (s, 1H), 8.44 (d, J $9.0 \mathrm{~Hz}, 1 \mathrm{H}), 8.38$ (d, J $8.5 \mathrm{~Hz}, 1 \mathrm{H}), 7.99$ (t, J 8.5 $\mathrm{Hz}, 1 \mathrm{H}), 7.89$ (t, J $8.25 \mathrm{~Hz}, 1 \mathrm{H}), 4.88$ (t, J $7.5 \mathrm{~Hz}, 2 \mathrm{H}), 2.11(\mathrm{~m}, 2 \mathrm{H}), 1.51-1.31(\mathrm{~m}, 8 \mathrm{H}), 0.90(\mathrm{t}$, J 7.25 Hz, 3H); ${ }^{13} \mathrm{C}$ NMR (125 MHz, CD $\left.{ }_{3} \mathrm{OD}\right)$ 163.6, 141.4, 130.9, 129.7, 125.7, 117.7, 108.6, 54.1, 32.2, 29.6, 29.3, 26.9, 23.0, 13.8; HRMS (EI) calcd for cation $\left[\mathrm{M}-\mathrm{CF}_{3} \mathrm{SO}_{3}\right]^{+} \mathrm{C}_{14} \mathrm{H}_{20} \mathrm{NS}$ : 234.1316, found: 234.1318 .

$\mathrm{N}$-Octylbenzothiazolium trifluoromethylsulfonate (10c). Yellow Solid; mp (DSC) $70.2{ }^{\circ} \mathrm{C}$; IR (neat) 2952, 2911, 2850, 1575, 1494, 1458, 1426, 1347, 1251, 1198, 1148, 1029, 872, $756 \mathrm{~cm}^{-1}$; ${ }^{1} \mathrm{H}$ NMR (500 MHz, CD 3 OD) 10.58 (s, 1H), 8.45 (d, J $\left.9.0 \mathrm{~Hz}, 1 \mathrm{H}\right), 8.39$ (d, J 8.5 Hz, 1H), 7.99 (t, J $8.75 \mathrm{~Hz}, 1 \mathrm{H}), 7.89$ (t, J $8.25 \mathrm{~Hz}, 1 \mathrm{H}), 4.89$ (t, J $7.75 \mathrm{~Hz}, 2 \mathrm{H}), 2.10$ (m, 2H), 1.51-1.25 (m, $10 \mathrm{H}), 0.89$ (t, J 7.00 Hz, 3H); ${ }^{13} \mathrm{C}$ NMR (125 MHz, CD $\left.{ }_{3} \mathrm{OD}\right)$ 163.2, 133.2, 131.7, 130.5, 126.5, 118.6, 109.4, 54.9, 33.1, 30.5, 30.4, 27.8, 23.9, 14.7; HRMS (EI) calcd for cation $\left[\mathrm{M}-\mathrm{CF}_{3} \mathrm{SO}_{3}\right]^{+}$ $\mathrm{C}_{15} \mathrm{H}_{22} \mathrm{NS}: 248.1473$, found: 248.1467.

$\mathrm{N}$-Nonylbenzothiazolium trifluoromethylsulfonate (11c). Yellow Solid; mp (DSC) $64.4{ }^{\circ} \mathrm{C}$; IR (neat) 3037, 2921, 2845, 1575, 1453, 1423, 1259, 1191, 1158, 1082, 1031, 887, 852, 758, 720 $\mathrm{cm}^{-1}$; ${ }^{1} \mathrm{H}$ NMR (500 MHz, CD $\left.3 \mathrm{OD}\right) 10.59$ (s, 1H), 8.46 (d, J 8.0 Hz, 1H), 8.40 (d, J 9.0 Hz, 1H), 7.99 (t, J $8.5 \mathrm{~Hz}, 1 \mathrm{H}), 7.88$ (t, J $8.25 \mathrm{~Hz}, 1 \mathrm{H}), 4.90$ (t, J $7.5 \mathrm{~Hz}, 2 \mathrm{H}), 2.11$ (m, 2H), 1.51-1.24 (m, 12H), 0.88 (t, J 7.0 Hz, 3H); ${ }^{13} \mathrm{C}$ NMR (125 MHz, CD $\left.3 \mathrm{OD}\right)$ 164.0, 141.7, 132.8, 131.3, 130.1, 126.1, 118.2, 54.5, 32.8, 30.3, 30.1, 30.1, 30.0, 27.4, 23.6, 14.3; HRMS (EI) calcd for cation [M$\left.\mathrm{CF}_{3} \mathrm{SO}_{3}\right]^{+} \mathrm{C}_{16} \mathrm{H}_{24} \mathrm{NS}: 262.1629$; found: 262.1623 .

$N$-Decylbenzothiazolium trifluoromethylsulfonate (12c). Yellow Solid; mp (DSC) $83.1{ }^{\circ} \mathrm{C}$; IR (neat) 2951, 2921, 2840, 1574, 1458, 1426, 1256, 1165, 1142, 1026, 872, 758, $718 \mathrm{~cm}^{-1} ;{ }^{1} \mathrm{H}$ NMR (500 MHz, CD 3 OD) 10.58 (s, 1H), 8.45 (d, J 8.0 Hz, 1H), 8.40 (d, J 8.5 Hz, 1H), 7.98 (t, J 
$8.5 \mathrm{~Hz}, 1 \mathrm{H}), 7.89$ (t, J $8.25 \mathrm{~Hz}, 1 \mathrm{H}), 4.91$ (t, J 7.5 Hz, 2H), $2.11(\mathrm{~m}, 2 \mathrm{H}), 1.51-1.25$ (m, 14H), 0.89 (t, J 7.0 Hz, 3H); ${ }^{13} \mathrm{C}$ NMR (125 MHz, CD $\left.3 \mathrm{OD}\right)$ 164.7, 141.7, 132.8, 131.3, 130.1, 126.1, 118.2, 54.5, 32.9, 30.5, 30.4, 30.3, 30.1, 30.0, 27.3, 23.6, 14.4; HRMS (EI) calcd for cation [M$\left.\mathrm{CF}_{3} \mathrm{SO}_{3}\right]^{+} \mathrm{C}_{17} \mathrm{H}_{26} \mathrm{NS}: 276.1786$, found: 275.1787 .

$\mathrm{N}$-Undecylbenzothiazolium trifluoromethylsulfonate (13c). Yellow Solid; mp (DSC) $75.3{ }^{\circ} \mathrm{C}$; IR (neat) 2911, 2840, 1577, 1496, 1464, 1426, 1350, 1254, 1142, 1026, 877, 758, $718 \mathrm{~cm}^{-1}$; ${ }^{1} \mathrm{H}$ NMR (500 MHz, CD 3 OD) 10.58 (s, 1H), 8.45 (d, J 8.5 Hz, 1H), 8.40 (d, J 8.5 Hz, 1H), 7.99 (t, J $7.75 \mathrm{~Hz}, 1 \mathrm{H}), 7.89$ (t, J $7.50 \mathrm{~Hz}, 1 \mathrm{H}), 4.89$ (t, J $7.75 \mathrm{~Hz}, 2 \mathrm{H}), 2.11$ (m, 2H), 1.51-1.25 (m, 16H), 0.89 (t, J 7.0 Hz, 3H); ${ }^{13} \mathrm{C}$ NMR (125 MHz, CD $\left.3 \mathrm{OD}\right)$ 164.1, 141.7, 132.8, 131.3, 130.1, 126.2, 118.2, 54.5, 32.9, 30.6, 30.5, 30.4, 30.3, 30.0, 27.4, 23.6, 14.3; HRMS (EI) calcd for cation [M$\left.\mathrm{CF}_{3} \mathrm{SO}_{3}\right]^{+} \mathrm{C}_{18} \mathrm{H}_{28} \mathrm{NS}: 290.1942$, found: 290.1937 .

$N$-Dodecylbenzothiazolium trifluoromethylsulfonate (14c). Yellow Solid; mp (DSC) $80.2{ }^{\circ} \mathrm{C}$; IR (neat) 2951, 2911, 2845, 1580, 1458, 1423, 1350, 1259, 1142, 1026, 875, 756, $718 \mathrm{~cm}^{-1} ;{ }^{1} \mathrm{H}$ NMR (500 MHz, CD 3 OD) 10.55 (s, 1H), 8.43 (d, J 8.0 Hz, 1H), 8.38 (d, J 8.5 Hz, 1H), 7.97 (t, J $8.5 \mathrm{~Hz}, 1 \mathrm{H}), 7.89$ (t, J $8.25 \mathrm{~Hz}, 1 \mathrm{H}), 4.89$ (t, J $7.5 \mathrm{~Hz}, 2 \mathrm{H}), 2.11$ (m, 2H), 1.50-1.19 (m, 18H), 0.89 (t, J 7.0 Hz, 3H); ${ }^{13} \mathrm{C}$ NMR (125 MHz, CD $\left.3 \mathrm{OD}\right)$ 164.0, 141.7, 132.9, 131.3, 130.1, 126.0, 118.1, 54.4, 32.9, 30.6, 30.5, 30.4, 30.3, 30.1, 30.0, 27.3, 23.6, 14.3; HRMS (EI) calcd for cation $\left[\mathrm{M}-\mathrm{CF}_{3} \mathrm{SO}_{3}\right]^{+} \mathrm{C}_{19} \mathrm{H}_{30} \mathrm{NS}: 304.2099$, found: 304.2102 .

\section{Thermal analysis}

For most of the salts (excluding $\mathbf{2 a}, \mathbf{3 a}, \mathbf{4 a}$, and $\mathbf{2 c}$ for which the melting points were analyzed visually with triplicate measurements), melting points were determined by differential scanning calorimetry (DSC) using a TA Instruments model 2920 Modulated DSC (New Castle, DE) cooled with a liquid nitrogen cryostat. The calorimeter was calibrated for temperature and cell constants using indium (mp $156.61{ }^{\circ} \mathrm{C}, \Delta \mathrm{H} 28.71 \mathrm{~J} / \mathrm{g}$ ). Data were collected at constant atmospheric pressure, using samples between $10-20 \mathrm{mg}$ in aluminum sample pans. Experiments were performed with heating at a rate of $10{ }^{\circ} \mathrm{C} / \mathrm{min}$. The DSC instrument was adjusted so that zero heat flow was between 0 and $-0.5 \mathrm{~mW}$, and the baseline drift was less than $0.1 \mathrm{~mW}$ over the temperature range $0-180{ }^{\circ} \mathrm{C}$. An empty sample pan was used as reference.

Thermal decomposition temperatures were measured in the dynamic heating regime using a TGA 2950 TA TGA. Samples between 5-15 mg were heated from $40-500{ }^{\circ} \mathrm{C}$ with isocratic heating rate at $10{ }^{\circ} \mathrm{C} / \mathrm{min}$ under an air atmosphere. Decomposition temperatures were determined from both (i) the onset to $5 \mathrm{wt} \%$ mass loss ( $\mathrm{T}_{5 \% \mathrm{dec}}$ ), which provides a more realistic representation of thermal stability at elevated temperatures, and (ii) from the onset to complete decomposition ( $\left.\mathrm{T}_{\text {onset}}\right)$.

\section{Single crystal $X$-ray diffraction analyses}

Samples were recrystallized from ethyl acetate by slow evaporation. Single crystals suitable for $\mathrm{X}$-ray analysis were isolated in air, mounted on fibers, and transferred to the goniometer. Singlecrystal X-ray diffraction data were collected on a Bruker CCD area detector-equipped 
diffractometer (Madison, WI) with graphite-monochromated Mo-Ka radiation $(\lambda=0.71073 \AA$ ). The crystals of 12a, 13a, and 14a were cooled to $-100{ }^{\circ} \mathrm{C}$ under a nitrogen gas stream during data collection. Absorption corrections were made with SADABS, and SHELXTL software was used for structure solution and refinement. ${ }^{38}$

Each structure was refined by using full-matrix least-squares methods on $F^{2}$. All atoms were readily located and the positions of all non-hydrogen atoms were refined anisotropically, where all hydrogens were located in calculated positions riding on the bonded atom. Disorder was found to be pronounced in the even-numbered chains for alkyl-substituted crystals (12a and 14a, $60 / 40 \%$ and $75 / 25 \%$, respectively) compared with the odd-numbered N-undecyl-substituted species, 13a. Disordered atoms were refined in alternate least squares cycles.

Crystallographic data (excluding structure factors) for the structures in this paper have been deposited with the Cambridge Crystallographic Data Centre as supplementary information; CCDC 750157, CCDC 750156 and CCDC 750158. These data can be obtained free of charge from The Cambridge Crystallographic Data Centre via www.ccdc.cam.ac.uk/data_request/cif.

\section{Acknowledgements}

SN is grateful to the HEC (Higher Education Commission) Pakistan for financial support of this work.

\section{References}

1. Anastas, P. T., Williamson, T. C., Eds. Green chemistry. Designing Chemistry for the Environment; ACS Symposium Series No. 626; American Chemical Society: Washington, DC, 1996, $251 \mathrm{pp}$.

2. Tundo, P.; Anastas, P.; Black, D. St C.; Breen, J.; Collins, T.; Memoli, S.; Miyamoto, J.; Polyakoff, M.; Tumas, W. Pure Appl. Chem. 2000, 72, 1207.

3. http://www.epa.gov/greenchemistry/pubs/principles.html, last accessed on July 7, 2009.

4. Earle, M. J.; Seddon, K. R. Pure Appl. Chem. 2000, 72, 1391.

5. Martins M. A. P.; Frizzo, C. P.; Moreira, D. N.; Zanatta, N.; Bonacorso, H. G. Chem. Rev. 2008, 108, 2015.

6. Davis, J. H.; Forrester, K. J. Tetrahedron Lett. 1999, 40, 1621.

7. Deetlefs, M.; Raubenheimer, H. G.; Esterhuysen, M. W. Catal Today 2002, 72, 29.

8. Barrett, A.G. M.; Love, A. C.; Tedeschi, L. Org Lett. 2004, 6, 3377.

9. Anjaiah, S.; Chandrasekhar, S.; Gree, R. Adv. Synth. Catal. 2004, 346, 1329.

10. Xu, L.; Tao, F.; Shen, X.; Yu, T. Huaxue Xuebao 1988, 46, 663.

11. Bakherad, M.; Bahramian, B.; Nasr-Isfahani, H.; Keivanloo, A.; Sang, G. Chin. J. Chem. 2009, 27, 353.

12. Miyashita, A.; Suzuki, Y.; Kobayashi, M.; Kuriyama, N.; Higashino, T. Heterocycles 1996, $43,509$. 
13. Castells, J.; Domingo, L.; Lopez-Calahorra, F.; Marti, J. Tetrahedron Lett. 1993, 34, 517.

14. Svetlichnyi, V. A.; Bazyl, O. K.; Artyukhov, V. Ya.; Kopylova, T. N.; Derevyanko, N. A.; Ishchenko, A. A. Opt. Spectrosc. 2007, 103, 753.

15. Stsiapura, V. I.; Maskevich, A. A.; Kuzmitsky, V. A.; Turoverov, K. K.; Kuznetsova, I. M. J. Phys. Chem. A 2007, 111, 4829.

16. Sabate, R.; Saupe, S. J. Biochem. Biophys. Res. Commun. 2007, 360, 135.

17. Kelenyi, G. J. Histochem. Cytochem. 1967, 15, 172.

18. Kitzman, P. H. Neurosci. Lett. 2009, 455, 150.

19. Marino, C.; Francesco, P.; Tetrahedron Lett. 2004, 4, 3633.

20. Chen, Y. T.; Jordan, F. J. Org. Chem. 1991, 56, 5029.

21. Lv, F.; Liu, Y.; Zou, J.; Zhang, D.; Yao, Z. Dyes Pigm. 2006, 68, 211.

22. Yao T. C.; Frank, J. J. Org. Chem., 1991, 56, 5029.

23. Xu, L.; Tao, F.; Shen, X.; Yu, T. Huaxue Xuebao 1988, 46, 663.

24. Ding, N.; Zhang, J.; Hor, T. S. A. Dalton Trans. 2009, 1853.

25. Nigrey, P. J.; Garito, A. F. J. Chem. Eng. Data 1977, 22, 451.

26. Ding, N.; Zhang, J.; Hor, T. S. A. Dalton Trans. 2009, 1853.

27. Jones, J. E.; Damschroder, R. E. US Pat. 2759821, 1956

28. Holbrey, J. D.; Seddon, K. R. J. Chem. Soc., Dalton Trans.: Inorg. Chem. 1999, 13, 2133.

29. (a) Auer, F.; Nelles, G.; Sellergren, B. Chem. Eur. J. 2004, 10, 3232, (b) Li, W. -T.; Yang, Y. -M.; Chang, C. -H. Coll. Surf., B 2008, 66, 187.,(c) Deng, M.; Yu, D.; Hou, Yanbo, H.; Wang, Y. J. Phys. Chem. B 2009, 113,8539.

30. Fuller, J; Carlin, R. T.; Osteryoung, R. A. J. Electrochem. Soc. 1997, 144, 3881.

31. Poole, C. F.; Kersten, B. R.; Ho, S. S. J.; Coddens, M. E.; Furton, K. G. J. Chromatogr. 1986, 352407.

32. Koch, V. R.; Nanjundiah, C.; Appetecchi, G. B; Scrosati, B. J. Electrochem. Soc. 1995, 142, L116.

33. Bonhote, P.; Dias, A.; Papageorgiou, N.; Kalyanasundaram, K.; Graetzel, M. Inorg Chem. 1996, 35, 1168.

34. Takaya, S.; Gen, M.; Kentaro, T. Electrochim. Acta 2004, 49, 3603.

35. Pardal, A. C.; Ramos, S. S.; Santos, P. F.; Reis, L.V.; Almeida, P. Molecules. 2002, 7, 320.

36. Anderson, J. L.; Armstrong, D. W.; Anal. Chem. 2003, 75, 4851.

37. Holbrey, J. D.; Reichert, W. M.; Swatloski, R. P.; Broker, G. A.; Pitner, W. R.; Seddon, K. R.; Rogers, R. D. Green Chem. 2002, 4, 407.

38. Levillain, J.; Dubant, G.; Abrunhosa, I.; Gulea, M.; Gaumont, A. C. Chem. Commun. 2003, 23, 2914.

39. Nigrey P. J and Garito A. F.J. Chem. Engg. Data 1977. 22. 451.

40. (a) Sheldrick, G. M.; Program for Semiempirical Absorption Correction of Area Detector Data, University of Göttingen, Germany, 1997; (b) Sheldrick, G. M.; SHELXTL, Version 6.14, Bruker AXS Inc., Madison, WI, 2003. 